\title{
Choice of Structure, Business Model and Portfolio: Organizational Models of Knowledge Transfer Offices in British Universities
}

\author{
Abhijit Sengupta and Amit S. Ray ${ }^{1}$ \\ Essex Business School, University of Essex, UK, and ${ }^{1}$ Centre for International Trade and Development, \\ Jawaharlal Nehru University, India \\ Corresponding author email: asengua@essex.ac.uk
}

\begin{abstract}
This paper addresses the gap in the knowledge transfer literature around how universities choose specific organizational models for their knowledge transfer offices (KTOs). Organization theory points towards strong interlinkages between strategy, structure and processes in organizations. This motivates an exploration of similar links within the organizational setup of KTOs. In doing so, the paper provides a unified theoretical framework around a university's choice of structure, business model and strategic preferences for their KTOs linked to university-specific contextual factors. A qualitative approach is used wherein four very distinct British universities are examined as individual case studies. The authors find that strategic aims of the university around practitioner engagement, the quantity of applied research and research specialization are key factors in determining the organizational characteristics of the KTO. The theoretical framework derived from the cases makes two key contributions to the university knowledge transfer literature. First, it links the university-level contextual factors to the local model of knowledge transfer. Second, it allows us to develop a set of generic models of knowledge transfer, which can potentially guide universities to develop their own specific models.
\end{abstract}

\section{Introduction}

University research and its subsequent impact on industry have been the focus of discussion in both academic and policy-making circles for a long

This project was funded by the JNU-Essex Development Fund (JEDF) administered by University of Essex, UK, and Jawaharlal Nehru University (JNU), India. The authors would like to thank all respondents from the universities of Oxford, Durham, Cranfield and Essex. Special thanks go to Dr Janice Pittis and Ville Karhusaari from the Research and Enterprise Office at Essex for their constant support. We are grateful to all participants of the ESRC sponsored Impact workshop held at University of Essex for very helpful comments and feedback. Finally, we would like to thank the anonymous referees whose helpful suggestions led to significant improvements in the paper. time (Acs, Audretsch and Feldman, 1992; Berman, 1990; Lee and Bozeman, 2005). Universities are no longer considered to be just 'ivory towers', solely for the creation of new knowledge and education, but are increasingly viewed as key players in the process of dissemination of this knowledge in forms useful to practitioners (Thursby and Thursby, 2002). Universities are increasingly considered to be 'entrepreneurial' (Etzkowitz et al., 2000; Guerrero and Urbano, 2012; Guerrero et al., 2016), and are seen to play a key role in driving entrepreneurship alongside innovation (Guerrero and Urbano, 2014). This connection between the traditional knowledge-creation function and the more recent knowledge exploitation function, often labelled 'knowledge transfer' (KT), has encouraged a growing body of literature 
examining its antecedents, impacts, role, motivation and engagement of key players (researchers, firms, universities). In contrast, relatively little attention has been paid to the organizational aspects of KT, the locally implemented framework within which it is carried out, and the choice made about various aspects of this framework by university managers and the Knowledge Transfer Office's (KTO) relationship with researchers (Huyghe et al., 2016; Perkmann et al., 2013).

Universities as organizations have evolved in their entrepreneurial outlook and developed relevant internal processes to support their increasingly important KT activities (Ambos et al., 2008; Phan and Siegel, 2006). Generally, such activities have been funnelled through dedicated administrative units linked to the university, acting as a conduit between university researchers and the external world. These administrative units, often referred to as the KTO, have grown in importance and are increasingly seen as crucial ingredients within the KT process of any university (Huyghe et al., 2016; Siegel, Veugelers and Wright, 2007).

Prior research examined the link between KT outcomes and KTOs from various perspectives, such as researchers' incentives (Lach and Schankerman, 2004; Link and Siegel, 2005), managerial incentives (Belenzon and Schankerman, 2009) and efficiency of KTOs (Chapple et al., 2005). However, systematic studies on KTOs themselves, their organizational characteristics, scope and role, are fewer and significantly narrower in focus (mostly limited to policies on managing disclosures, patenting, licensing and spinout activities). At the same time, these studies have viewed KTOs from a unidirectional perspective, where given characteristics of a KTO are examined for impact on specific outcomes (for researchers, universities, industries or the economy). It has, however, been established that KTOs are also willing to explore new models and paradigms of KT (Martin, 2012; Sharifi, Liu and Ismail, 2013), and the changes they themselves undergo should not be overlooked.

Knowledge Transfer Offices do not function in isolation from the rest of the university and are governed by the same overarching principles and strategies of the parent organization. Hence, it is expected that the KT processes, the KTO's structure, its preferred modes of interaction and its relationship with the rest of the organization will be conditioned by the university's own context, history and characteristics. In fact, KTOs coevolve with the parent organization over time, i.e. changes to the university are reflected in the KTO as well. This in turn has implications on the impact generation and entrepreneurial processes being channelled through the KTO, thus modifying the KT interface (Lockett et al., 2005).

It is well established that entrepreneurial universities should embrace the need for change in response to the emerging external business environment (Siegel and Wright, 2015; Siegel, Veugelers and Wright, 2007). The need for a university to have a dynamic and entrepreneurial outlook is increasingly seen as crucial, given that the overall economic climate has been in a constant state of flux in recent years (Etzkowitz et al., 2000; Guerrero et al., 2016; Miller, McAdam and McAdam, 2014). Knowledge Transfer Offices play the role of a coordinator, champion and the 'institutional entrepreneur' in the KT process (Siegel, Veugelers and Wright, 2007), and hence the overarching changes in the university are mirrored in them (Sharifi, Liu and Ismail, 2013).

This paper examines how the organizational characteristics of KTOs are shaped by the local contextual characteristics of the university in which they are situated. It explores the links between the university context, particularly organizational strategy and nature of research carried out, with how its KTO is structured and managed. Taking an inductive approach, this study extends the theoretical understanding of how universities and their KTOs shape a local model of KT, based on their specific needs. This is supported through a set of qualitative case studies, which explore a set of specific models of KT in the UK and their links with university specific factors.

Organizational literature has indicated that interlinkages exist between overall strategy and structure (Cummings and Worley, 2015) and that centralization, specialization and differentiation are key factors behind the success of innovative organizations (Damanpour, 1991; Wolfe, 1994). This leads us to focus on three aspects of a KTO's activities within an entrepreneurial university. First is its structure, i.e. the nature of its relationship with internal stakeholders within the university. That the structure of a KTO is crucial in determining KT outcomes has been established (Bercovitz et al., 2001), but how structure itself is determined within 
the context of the university, is yet unexplored (Perkmann et al., 2013). Second is its business model, i.e. its relationship with the external stakeholders such as intermediaries and specialists who provide specific support for KT. The role of intermediaries in innovation and $\mathrm{KT}$ has been recognized in the literature, but little attention has been paid to antecedents of these relationships (Hayter, 2016; Howells, 2006; Wright et al., 2008; Yusuf, 2008). Third, we examine a KTO's strategic preferences over a multitude of KT pathways and how these preferences are determined at the organizational level. Our study develops a unified theoretical framework, providing a mechanism to explain a university's choices along these dimensions.

The results reveal clear links between the context and the university's choice of its KT framework, which are presented in a set of propositions mapping university-level characteristics to the KTO's organizational features. A set of generic KT frameworks are derived, which can act as a template for universities to implement or adapt, based on local needs. These findings are of relevance to university managers looking to explore new models of KT or improve the current ones. They are also interesting from a policy perspective, as they address the issue of heterogeneity among universities, in terms of both performance and internal organizational models.

The rest of the paper is organized as follows. In the second section, we provide the background and motivation for our research in terms of the extant literature and its gaps. In the third section, we describe the methodology adopted in our analysis. This is followed by the main findings in the fourth section. The fifth section discusses these findings, puts forward the propositions and the resulting theoretical implications, and the paper concludes in the final section. The Supplementary Material provided alongside this paper carries detailed discussion of the data used here and further analysis.

\section{Background}

While prior studies have focused on one or more antecedents of $\mathrm{KT}$, the literature lacks a unified theoretical framework incorporating organizational and institutional factors affecting the local model of KT in universities (Perkmann et al.,
2013). There is little theoretical guidance on how a university chooses among the alternative channels of Research Commercialization (RC) and Academic Engagement (AE), how a KTO organizationally adapts itself in response to such choices, and what internal processes are put in place in order to support KT through these channels. This absence in the extant literature, particularly the organizational aspects of KTOs, is proving to be critical for two important reasons.

First, universities operate within an external environment which has become increasingly competitive and constrained (Miller, McAdam and McAdam, 2014; Siegel and Wright, 2015). Engaging with industry is no longer restricted to a handful of universities, but is increasingly treated as important by all. Lockett, Wright and Wild (2015) comprehensively argue that 'third stream' activities have become institutionalized in universities in response to changes in the external environment. At the same time, universities have become increasingly entrepreneurial and have started to play a key role in developing an entrepreneurial outlook and culture (Etzkowitz et al., 2000; Guerrero and Urbano, 2012; Guerrero et al., 2016). Secondly, as universities have become more entrepreneurial, models of KT have undergone radical changes in recent years (Etzkowitz et al., 2000; Miller, McAdam and McAdam, 2014). Knowledge Transfer Offices have not remained as static entities and have used 'learning processes' to adapt their relationships with external partners, given a changing external environment (Weckowska, 2015). Knowledge Transfer Offices have also had to adapt with respect to the university's changing internal environment, to establish their own unique identity (O'Kane et al., 2015).

It is well established that organizations restructure and reorient their processes, reflecting changes in strategy and tactics (Cummings and Worley, 2015; Miles et al., 1978). Universities have had to adapt strategically to the changing external environment and as their third-stream activities have gained in importance and focus (HewittDundas, 2012; Siegel, Waldman and Link, 2003; Slaughter and Leslie, 1997). Starting from investments into parallel strands of activities and infrastructure (Ambos et al., 2008), to managerial and academic incentives for KT (Belenzon and Schankerman, 2009; Lach and Schankerman, 2004; Link and Siegel, 2005), to how universities 
react to institutional changes reflecting the growing importance of research impact (Martin, 2012), strategic motives have been key in driving organizational changes around KT. Hence an examination of how a KTO's internal structure is adapted in response to strategic and tactical considerations of the university is critical in understanding its KT model.

Structural aspects of a KTO concentrate on the internal relationships and mechanisms of the KT model in a university, primarily on how the KTO interacts with researchers, departments and Schools. However, a KTO is an outward-facing organization with the remit of facilitating links between university's research and its potential end users. Maintaining an external orientation by building up networks of external stakeholders is a critical component in any entrepreneurial venture, and the KTO is no exception (Brettel, Chomik and Flatten, 2014). The role of knowledge intermediaries, who can be used as a conduit between the university-based KTO and industry-based clients, has become increasingly important (Hayter, 2016, Wright et al., 2008). The nature of these external relationships has impacted the overall 'business model' of KTOs themselves as well as their day-to-day operations.

Alongside internal and external relationships of KTOs, there has been a sector-wide shift in the various modes of interaction with industry, with the AE channels increasingly becoming the dominant mode of KT (Perkmann, King and Pavelin, 2011), and this reflects a major paradigm shift in the way KTOs function. The IP-centric RC route and institutional setup was based on the premise of a unidirectional flow of knowledge and technology from universities to industry, mediated by the KTOs (Geuna and Rossi, 2011). However, the AE channels encourage a bidirectional flow of knowledge, where university researchers and external users of research are both involved in the knowledge creation process (Bekkers and Bodas Freitas, 2008; Perkmann and Walsh, 2007). From being narrowly focused administrative units dealing with RC only, KTOs have increasingly adopted a multitude of pathways (Perkmann et al., 2013) and are seen to deal with a large portfolio of contracts and contract types.

Appropriate structure, business model and strategic preference over channels are some of the key organizational aspects of a KTO, enabling it to respond optimally to demand and the changes in the environment. We now discuss each of these aspects in further detail.

\section{Internal relationships: structure}

Organizational theory has explored the role of structure in the evolution of the modern enterprise (Chandler, 1962). The choice of a centralized vs. decentralized structure has implications on how teams function and interact, and how critical organizational processes are incorporated (Chen and Huang, 2007). Knowledge Transfer Offices themselves are organizational sub-units within universities with their own mandate, dedicated manpower and with a reasonable degree of autonomy. The 'customers' of the KTO include the rest of the university staff, including academic researchers, research-related administrative personnel and external stakeholders. The question that arises naturally is: what is the ideal structure for a KTO, given its local circumstances? And how does this structure evolve, based on changing local circumstances.

Organizational strategy and structure have been established as being highly interdependent and are viewed as complementary factors for success (Miller, 1987). There is evidence to show that organizations involved with knowledge management may prefer more devolved structures from a strategic perspective (Hedlund, 1994). Hence, it is important to understand how a KTO will structure itself within the larger more complex organization, i.e. the university.

These questions have been only partially addressed in the literature. Bercovitz et al. (2001) examined the structure of three independent KTOs in the US, and compared the model in each along the dimensions of information-processing capacity, coordination capability and incentive alignment. They juxtaposed the observed models on four alternative theoretical structures proposed in Chandler (1962) and Williamson (1975, 1985): the U-Form or a centralized unitary structure; the M-Form or a centralized but disaggregated structure; the H-Form or a decentralized and disaggregated structure; and finally, the MX-Form or a matrix structure. Bercovitz et al. (2001) postulate that these alternative structures have different impact on the functioning and efficiency of the KTOs and use the data from the three organizations to show that their underlying structures do have an impact on overall levels of KT. The structure of 
each university was treated as an independent variable in the analysis, with the focus around its impact on the three dimensions mentioned above.

While Bercovitz et al. (2001) provides the starting point of examining the relationship between the structure of a KTO and university-level KT outcomes, treating 'organizational structure' as an exogenous variable misses the complexity and evolving nature of a KTO with respect to the history, context and external pressures faced by universities. Debackere and Veugelers (2005) study several universities and emphasize the role of 'decentralization' in KTO structures, in order to capture better the variety of research within the organization. But previous research has not addressed the question of why certain KTOs adopt a centralized structure and why certain others do not. This paper aims to address this gap, by examining how a KTO's structure can be determined by local university-related contextual factors.

\section{External relationships: business model}

A key criterion underpinning an entrepreneurial organization's success is its business model (Morris, Schindehutte and Allen, 2005). The business model is shaped not just through its internal processes, but also through its relationship with external stakeholders. 'Outsourcing' of key internal functions and processes is increasingly seen as an important component of business models. It has been argued that outsourcing leads to efficiency gains through overall cost reductions and access to specialist knowledge and capabilities. Outsourcing as a business model is well established in industry, typically in relation to information systems, services and back-office functions. While the benefits and costs of implementing a model based on outsourcing has been debated (Belcourt, 2006; Lee and Kim, 1999), it has been shown to improve efficiency for knowledge and IP-based services (Quinn, 1999).

Knowledge Transfer Offices have increasingly adapted an external outlook using knowledge intermediaries and specialists to carry out some of its core functions (Hayter, 2016, Wright et al., 2008). This is one key aspect of KTO's operations that has largely been overlooked in the extant literature, but which is becoming extremely relevant (Yusuf, 2008). Such intermediaries are usually specialists in certain areas, ranging from patent attorneys to technology scouting to financing, and increasingly to specialist companies undertaking multiple aspects of RC and AE on behalf of the university.

With institutional and policy changes altering the pressures on universities and academic researchers to demonstrate the impact of their research more explicitly (Haeussler and Colyvas, 2011; Lee, 1998; Mowery and Sampat, 2005), KTOs may expect to manage increasingly greater volumes of potentially applicable research outputs and greater volumes of contracts in the future. Hence, outsourcing of key operations to external stakeholders is a business model that can no longer be ignored by KTOs. In this paper, we explore whether this outsourcing decision, in turn, relates to the context and organizational characteristics of the university itself.

\section{Strategic preferences: portfolio}

Knowledge transfer from universities is not a homogeneous phenomenon, but takes multiple forms, and may be carried out through number of alternative pathways (Hewitt-Dundas, 2012; Rossi and Rosli, 2015). In a comprehensive review of the literature, Perkmann et al. (2013) categorizes them into two independent streams - RC and AE (Figure 1).

Research Commercialization encompasses strategies used to commercially exploit intellectual property generated through market mechanisms, involving patenting, licensing, spinouts and related entrepreneurial activities. Research on KT had largely focused on RC activities (Siegel and Wright, 2015; Siegel, Veugelers and Wright, 2007; Siegel, Waldman and Link, 2003), since KTOs mushroomed largely in response to intellectual property legislations in many countries aiming to provide an institutional framework through which universities could patent and license their research (Mowery and Sampat, 2005; Mowery et al., 2004; Ray and Saha, 2010; Wright et al., 2007).

It has, however, been established that universities have looked well beyond the market-driven $\mathrm{RC}$ routes in creating impact through KT (Geuna and Rossi, 2011; Lockett, Wright and Wild, 2015; Perkmann et al., 2013; Rossi and Rosli, 2015). At least as far as the UK is concerned, these occupy a much larger proportion in terms of volume and value compared with the IP route. The most prominent of these alternative channels are contract research, collaborative research and consultancy, which are clubbed together under 


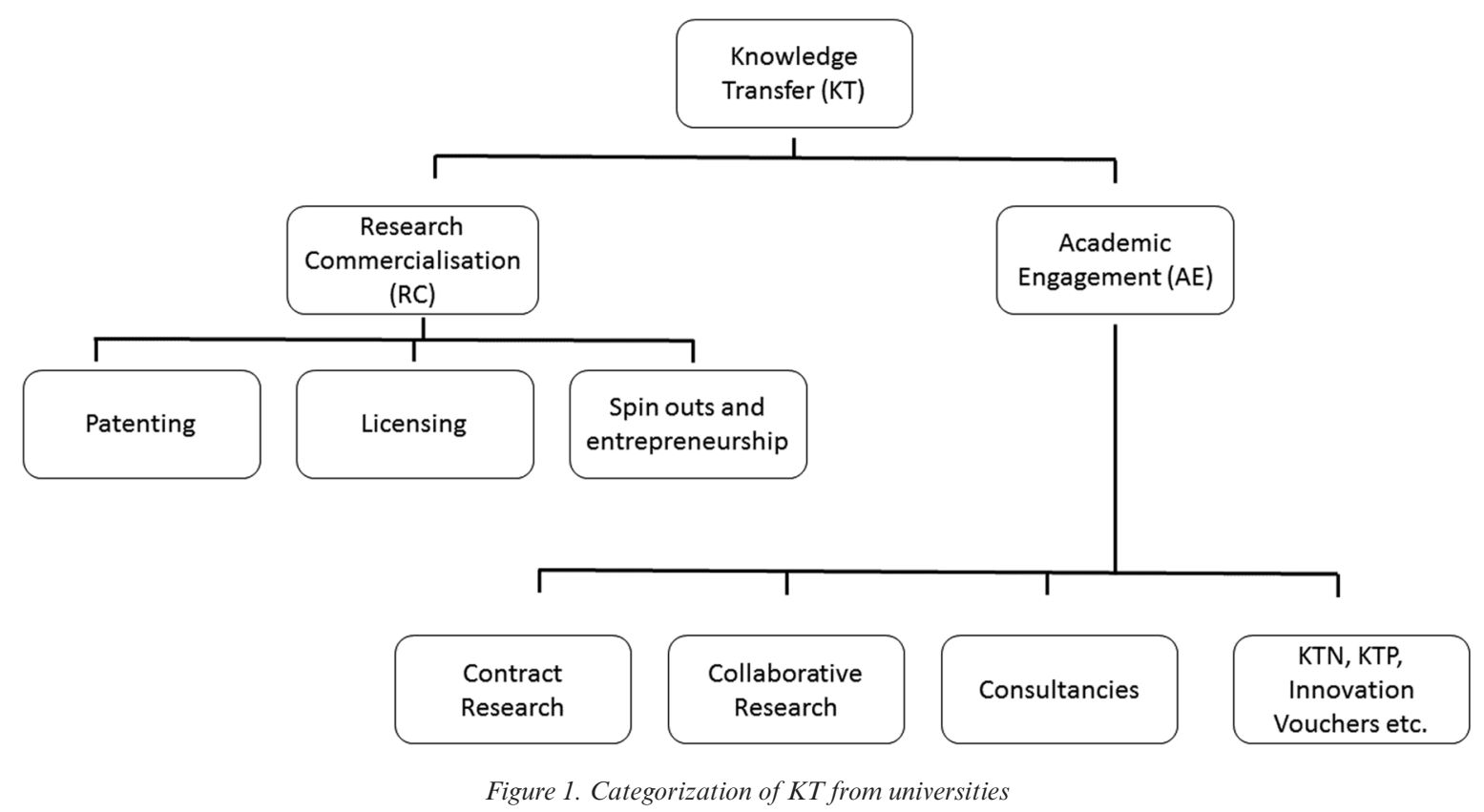

AE. ${ }^{1}$ Academic Engagement channels largely involve 'knowledge related collaborations by academic researchers with non-academic organisations' (Perkmann et al., 2013), rather than a clearly defined market mechanism, as seen in RC.

We adopt the terminologies of RC and $\mathrm{AE}$ to refer to the alternative modes of KT for the rest of the paper. This makes a clear distinction between the more collaborative $\mathrm{AE}$ routes involving some element of knowledge co-creation with partners vs. the market oriented $\mathrm{RC}$ routes indicating 'sale' of technology and knowhow.

The third organizational aspect examined here is the university's preference over alternative KT mechanisms. Universities have increasingly become more strategic in their approach to industry engagement in general and commercialization in particular (Lockett et al., 2005; Siegel and Wright, 2015; Siegel, Veugelers and Wright, 2007). For example, AE channels, specifically contracts and collaborations are increasingly the dominant channels, and universities seem have responded

\footnotetext{
${ }^{1}$ In UK universities, IP-related income accounted for 2 $3 \%$ of total income coming to the sector between 2003-04 and 2012-13. Contract research accounted for 32\%, followed by collaborative research $(25 \%)$ and consultancies $(11 \%)$. Other, such as Continued Professional Development (CPD), Continued Education (CE), Facilities and Equipment lease accounted for the rest (Source: HE-BCI Report, 2014).
}

to the non-profitability of the patent/licensing model (D'Este and Perkmann, 2011; Perkmann et al., 2013). In a Europe-wide study, however, Geuna and Nesta (2006) find that patenting in universities seem to be on the rise, although it remains heterogeneous across institutions and disciplines. They also find that licensing is largely not profitable for universities. However, what is not well understood is the following: do KTOs prefer or prioritize any specific channels, and if so, exactly what determines the priority ordering?

While the trends in RC are relatively straightforward to evaluate, given the well-structured data available on patents, patent citations, spin-out formation and, to a lesser extent, on licensing deals, evaluating AE channels may be difficult given the absence of a market mechanism. While survey data from universities do provide overall volume and value figures relating to specific $\mathrm{AE}$ routes, they do not reveal the strategic priorities and preferences of the KTOs themselves. ${ }^{2}$ However, with growing evidence that external partners consider AE routes more valuable than RC (Cohen, Nelson and Walsh, 2002; Perkmann, King and Pavelin, 2011),

\footnotetext{
${ }^{2}$ In the case of the UK, the HE-BCI survey questionnaires (Part A) do contain information about strategic directions etc., but the questionnaire is largely focused on the use of innovation funds that universities receive from public sources. Preferences about KT routes are not explicitly asked, and seldom addressed.
} 
understanding the choices made by KTOs at an organizational level becomes critical.

\section{Conceptual framework}

Our paper links these key organizational characteristics to the local context of a university within a unified theoretical framework. Unlike Bercovitz et al. (2001), these are treated as endogenous, implying that the KT frameworks are determined by local factors and are not considered as given. As discussed above, the importance of these three characteristics in defining a KTO's identity is well established in the KT literature. In fact, organizational literature also points towards centralization, specialization and differentiation (Damanpour, 1991; Wolfe, 1994) as key determinants of the innovative behaviour in organizations. These can be linked directly to the organizational characteristics of KTOs being discussed here - namely, structure, business model and preference, and hence form the basis of the theoretical contribution being made here in relation to entrepreneurial universities.

The extant literature has established several contextual factors that could affect a university's choices about how KT is organized and its performance. Primary among these are quality, quantity and breadth of research output of the university (D'Este and Patel, 2007; Hewitt-Dundas, 2012; Perkmann and Walsh, 2009; Sengupta and Ray, 2015). Additional key factors discussed in previous literature are the nature of incentives for staff (Belenzon and Schankerman, 2009; Link and Siegel, 2005; Siegel, Waldman and Link, 2003), and university-level heterogeneity indicated through age, location, size and nature of links with industry (Azagra-Caro et al., 2006; D'Este and Patel, 2007; Ponomariov and Boardman, 2008). Our study does not ignore these, but, rather, directly incorporates them within the contextual background of the university. While previous literature has linked these with KT performance, in this paper we examine their effect on the KT framework.

However, it is difficult to examine any KT framework divorced from KT performance. It is likely that there is a medium- to long-term link between framework and performance in entrepreneurial universities, as is seen in entrepreneurial firms (Cosh, Fu and Hughes, 2012). Hence, we consider performance as a part of the context that influences the locally implemented KT model.
The role of overall university strategy with regard to research and $\mathrm{KT}$ is under examination in the literature. It is being recognized increasingly that universities may engage in KT through multiple pathways, involving multiple disciplines (Hughes and Kitson, 2012; Rossi and Rosli, 2015). Deiaco, Hughes and McKelvey (2012) point out that they are also required to respond strategically to external pressures of funding, policy changes and changes in the entrepreneurial climate. As an organization, top-level strategic changes will have an impact on its internal practices and processes, including the KTO - and hence is also included in our model as a contextual factor.

The overall conceptual framework underlying this study is presented in Figure 2. The local context of the university, incorporating research, strategy, KT performance, incentive structures and overall reputation drives the local KT model. Three aspects of the model, namely, structure, business model and strategic preferences, are examined, and the model maps the contextual factors on these aspects of the KT model.

\section{Methodology}

This paper adopts a case study approach to examine the impact of context on the KT framework of a university within the British $\mathrm{HE}$ sector. This approach provided us with the flexibility to interrogate the models adopted in each of the cases thoroughly, considering the context of the university. Given the absence of existing holistic models of KT framework in the extant literature, these cases allowed us to develop a set of propositions connecting a university's characteristics to its adopted KT framework.

Gibbert, Ruigrok and Wicki (2008) and Eisenhardt and Graebner (2007) emphasize that sampling of the appropriate cases is a key step in developing a robust case study. Given the central research questions, we wanted to consider cases that not only pointed toward significant differences in the underlying KT models themselves, but also universities whose local contexts varied significantly from each other. The UK Higher Education Statistical Agency (HESA) makes available very detailed university-level data on many aspects of universities in the UK, including research outputs and KT. We carried out a clustering analysis to classify all degree-awarding universities in the UK 


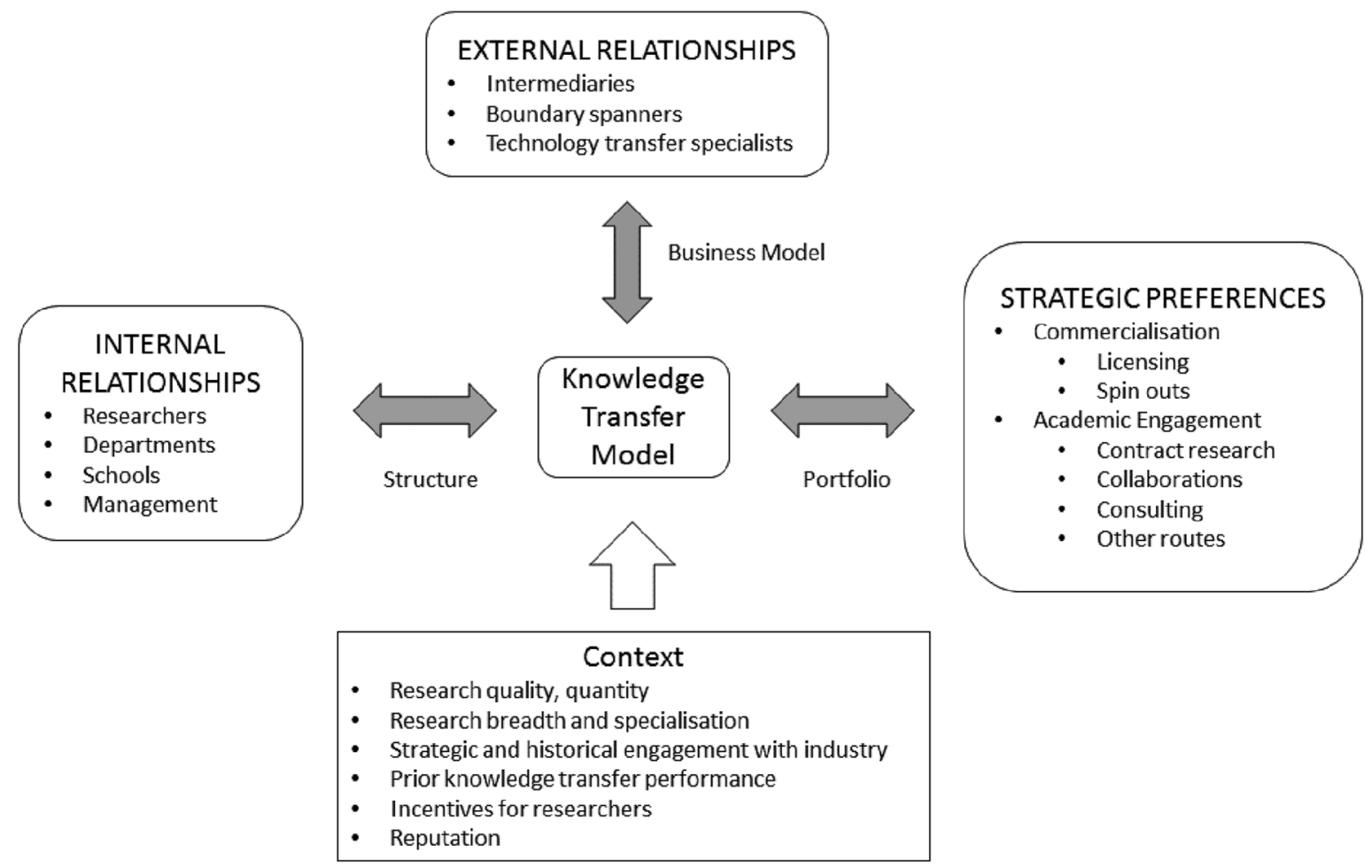

Figure 2. The conceptual framework linking university-level contextual factors to the model of KT

on performance along the three dimensions of research commercialization, academic engagement and research-related activities. ${ }^{3} \mathrm{~A}$ set of candidate universities were selected to ensure a good spread across the clusters in all three areas. Finally, given the availability and willingness of respondents, four universities were selected for this study, and these were the universities of Oxford, Durham, Essex and Cranfield.

Oxford and Durham are Russell Group universities, with a very long history, a wide research base and of relatively large scale. In contrast, both Cranfield and Essex are relatively newer universities with a significantly narrower focus in research and are of a small scale than Oxford or Durham. Cranfield is a post-graduate university with 'research and development portfolio solely focused on technology and management', while Essex has a strong research base in the social sciences and humanities. Quantitative data (HE-BCI surveys) from the UK Higher Education sector reveals that

\footnotetext{
${ }^{3}$ The results of the clustering analysis and the relevant methodology are presented in the Supplementary Material.
}

all four universities vary significantly in the overall performance in KT-related activities (Figure 3).

Given the key role that local context plays in this research, we adopted the qualitative approach in our research methodology. We gathered primary data through in-depth interviews of key senior KTO personnel and academic researchers in each of the universities, using semi-structured questionnaires. A semi-structured approach was preferred, given the variation in the organization and culture of the KTOs and the universities. This approach gave us the flexibility to probe into the local KT models as needed and examine their strengths and weaknesses. The list of guiding questions, which formed the underlying basis of the interviews for both KTO management and researchers, can be found in the Supporting Information.

In terms of the interviewees, the key point of contact was the Director (or equivalent) of each of the KTOs. Each was interviewed over two to three sessions, a session lasting between one and two hours. Additional senior managerial personnel were also approached for more information on recommendation from the Director. Moreover, selected faculty members who have undertaken 
Income from RCUK and Non-HE sources (2009-10 to 2011-12)

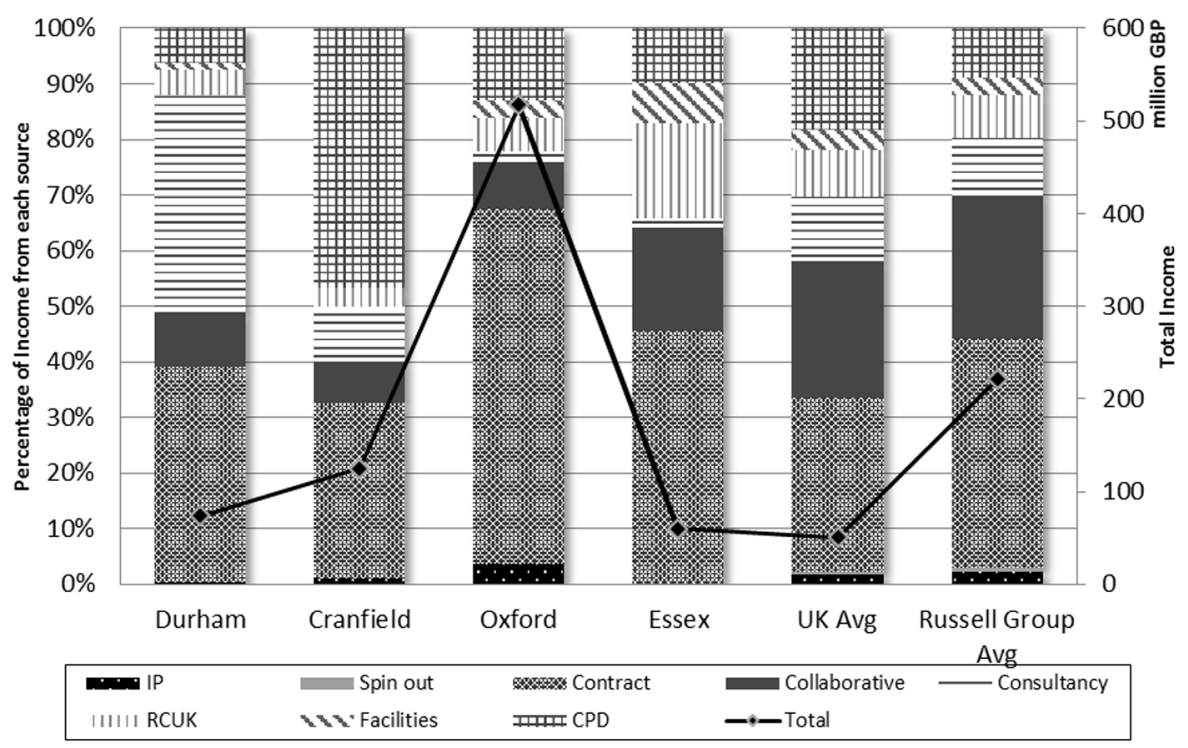

Figure 3. Income from research councils and non-HE sources (2009-10 to 2011-12), total and percentages. Excludes research income from $E U$ and other funding bodies

KT within the current organizational setup were also approached with a separate questionnaire for their feedback on the whole process and experience. In all, 16 individuals were interviewed across the four universities between April 2013 and December 2013, either in-person or by telephone.

All interviews were transcribed and then coded over multiple rounds. The coding exercise was designed to reveal both contextual features of the universities as well as the characteristics of the locally implemented KT model. The coding revealed two complementary sets of dominant themes, which formed the basis of subsequent analysis. Table 1 provides a taxonomy of the themes used in the analysis, and Table 2 presents a set of examples of the themes and their relation to the transcribed data.

The first set consisted of a collection of emerging themes, which were labelled: strategy; tactics; external orientation; and performance. These themes revealed insights into the local context around each case. We label them as 'emerging', as the interview questions did not probe directly for these, but arose spontaneously from the coding exercise. The second set of themes consisted of a collection of descriptive themes, which represented descriptions of the locally implemented KT model. These themes were chosen by the authors and explored actively through the questionnaire. These are labelled: structure; model; preference; scale; change; operations; and research. Based on this thematic exercise, each case was analysed for its locally implemented KT framework and context.

\section{Findings}

The four universities chosen for the cases studies are characteristically very different from each other, both in the KT model they have adopted and in the context in which they operate. Here we present a comparison of these universities based on the three organizational characteristics, with the help of the thematic analysis of the primary data. Tables 3-6 present the detailed thematic analyses of all the cases based on the two sets of themes: emergent and descriptive. Table 7 summarizes each of the cases with respect to research, the locally implemented KT framework and performance across RC and AE channels. The accompanying Supporting Information contains a more detailed description of each case, although all salient points can be found in the discussions below.

\section{Structure}

The IP management and KT setup in Oxford is organized under two parallel strands: Research 
Table 1. Taxonomy of themes used in the analysis of primary data

\begin{tabular}{|c|c|c|c|}
\hline Type/Theme & Meaning and association & Type/Theme & Meaning and association \\
\hline Emergent themes & $\begin{array}{l}\text { Themes revealing information about the } \\
\text { local university context. The questions } \\
\text { did not probe directly but were allowed } \\
\text { to emerge organically from the data and } \\
\text { coding. }\end{array}$ & Descriptive themes & $\begin{array}{l}\text { Themes revealing information about the } \\
\text { locally implemented model of KT. The } \\
\text { questions probed directly for these } \\
\text { themes. }\end{array}$ \\
\hline Strategy & $\begin{array}{l}\text { Overall direction, long-term vision and } \\
\text { goals. }\end{array}$ & Structure & Centralization or devolution of activities. \\
\hline Tactics & $\begin{array}{l}\text { Steps implemented to achieve strategic } \\
\text { aims or short term vision and goals. }\end{array}$ & Model & $\begin{array}{l}\text { Degree of outsourcing or use of external } \\
\text { agency. }\end{array}$ \\
\hline External orientation & Awareness about external world; learning. & Preference & $\begin{array}{l}\text { Stated or revealed preference on channels } \\
\text { of KT or any other activity. }\end{array}$ \\
\hline \multirow[t]{4}{*}{ Performance } & $\begin{array}{l}\text { Measure or qualitative judgement about } \\
\text { levels of KT, research and other } \\
\text { activities. }\end{array}$ & Scale & Quantity or breadth of activity. \\
\hline & & Change & $\begin{array}{l}\text { Aspects of past or ongoing changes within } \\
\text { organization or externally. }\end{array}$ \\
\hline & & Research & Quality, quantity, nature of research. \\
\hline & & Operations & Processes, standards, regular activities. \\
\hline
\end{tabular}

Services, an organizational sub-unit of the university responsible for the bulk of AE; and Oxford University Innovation (OUI), a wholly owned but external subsidiary of the university responsible for the bulk of RC. ${ }^{4}$ Structurally, the KTO's activities are mostly centrally managed, but management of spinouts and entrepreneurship have been devolved to the departments.

For Durham, the Durham Business \& Innovation Services (DBIS), an office within the university, plays the role of a gatekeeper to all the university's KT activities. Structurally, Durham has adopted a centralized model for its KTO, except for contract research, which is mostly channelized through departments and research centres directly. Durham Business \& Innovation Services has a wide remit in terms of providing KT support and increasingly plays an anchor role in crossdepartmental research collaborations as well.

Essex is similar to DU in this respect, as the Research and Enterprise Office (REO) undertakes the role of a KTO, is centrally managed, with dedicated personnel looking after all its faculties.

Cranfield is split into five Schools, each of which is treated as an independent business, and each has its own responsibility for generating research income and ensuring financial viability. Consequently, they are divested with a lot of autonomy regarding the choice of KT strategies. Structurally, it follows a fully decentralized

${ }^{4}$ Until mid-2016, and at the time of the data collection, OUI was known by the name of ISIS Innovation. approach, where most key functions of a KTO are devolved to Schools, faculties and departments within the university. These units are incentivized accordingly for carrying out AE activities. The faculty members are also incentivized directly, so that technology transfer is an important factor within their research and career considerations.

\section{Business model}

The business model observed in Oxford's KT framework shows a clear division in roles between those organizational units internal to the university and those external to it. The patenting and licensing aspects of $\mathrm{RC}$ and consulting in AE have been outsourced to OUI. Contracts and collaborations, in contrast, are managed in-house by Research Services and within the faculties and departments themselves. The case of Cranfield is somewhat similar in that most $\mathrm{RC}$ management has been outsourced (to OUI), while management of $\mathrm{AE}$ activities is located internally, but devolved into the Schools and departments.

For Durham, all KT functions are located wholly internally to the university, with both RC and AE management brought within DBIS following re-evaluation and restructuring in 2008. Similarly, all key operations in Essex have been located internally with the REO.

\section{Portfolio}

As part of its portfolio preference, Oxford explicitly states that all RC and AE channels are 
Table 2. Examples of thematic classification of primary data collected from the four universities

\begin{tabular}{|c|c|c|c|c|}
\hline University & Unit & Commentary & $\begin{array}{c}\text { Emerging } \\
\text { themes }\end{array}$ & $\begin{array}{l}\text { Descriptive } \\
\text { themes }\end{array}$ \\
\hline \multicolumn{5}{|l|}{ Oxford } \\
\hline & RS & $\begin{array}{l}\text { Research services manages pre- and post-award support, } \\
\text { contracts and impact. }\end{array}$ & Strategy & Operations \\
\hline & RS & $\begin{array}{l}\text { ISIS looks after most of the IP-related transactions and } \\
\text { consulting. }\end{array}$ & Strategy & Model, operations \\
\hline & RS & $\begin{array}{l}\text { We interact closely with other regional players to build an } \\
\text { ecosystem. }\end{array}$ & External orientation & Operations \\
\hline & OUI & $\begin{array}{l}\text { We have been very successful with licensing, with over } 20 \% \\
\text { patents licensed out. }\end{array}$ & Performance & Preference \\
\hline & OUI & $\begin{array}{l}\text { The primary aim underlying all our licensing activity is } \\
\text { maximizing the number of contracts, not revenue. }\end{array}$ & Strategy & Preference \\
\hline & OUI & We provide access to Oxford's world class expertise. & External orientation & Operations \\
\hline & Faculty & $\begin{array}{l}\text { The arrangement with ISIS is working well ... can't see reasons } \\
\text { for major changes in the near future. }\end{array}$ & Tactics & Change \\
\hline \multicolumn{5}{|c|}{ 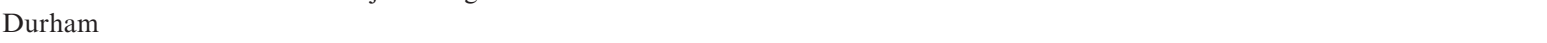 } \\
\hline & DBIS & $\begin{array}{l}\text { Nowadays we put less priority on patents and licensing by } \\
\text { themselves ... spinouts are being maintained although the } \\
\text { sector as a whole haven't done well in this regard. }\end{array}$ & Strategy & Preference \\
\hline & DBIS & $\begin{array}{l}\text { We are encouraging more collaborative research with industry } \\
\text { following general trends in the sector. }\end{array}$ & $\begin{array}{l}\text { Strategy, external } \\
\text { orientation }\end{array}$ & Preference \\
\hline & DBIS & $\begin{array}{l}\text { DBIS underwent a restructuring a few years back and as a } \\
\text { result, commercialization and enterprise activities were } \\
\text { brought under the same roof. }\end{array}$ & Strategy, tactical & Structure, change \\
\hline & DBIS & $\begin{array}{l}\text { Spinout success has generally been declining in the UK ... we } \\
\text { are still waiting for the big exits to take place. }\end{array}$ & External orientation & Change \\
\hline & DBIS & Multidisciplinarity definitely helps in industrial collaborations. & Tactical & Research \\
\hline & Faculty & $\begin{array}{l}\text { DBIS carried out detailed discussions regarding potential for } \\
\text { commercialization. }\end{array}$ & Tactical & Operations \\
\hline & Faculty & $\begin{array}{l}\text { It's good to have all services centrally located, my experience } \\
\text { from previous employment wasn't great where they had } \\
\text { outsourced. }\end{array}$ & $\begin{array}{l}\text { External orientation, } \\
\text { tactical }\end{array}$ & Model, operations \\
\hline \multicolumn{5}{|l|}{ Cranfield } \\
\hline & KTO & $\begin{array}{l}\text { Faculty encouraged to be entrepreneurial, so may take things in } \\
\text { their own hands. }\end{array}$ & Strategy & Structure, operations \\
\hline & KTO & $\begin{array}{l}\text { We had a larger internal team with wider remit previously but } \\
\text { significantly overhauled in 2006, and subcontracting model } \\
\text { put in place. }\end{array}$ & $\begin{array}{l}\text { Strategy, external } \\
\text { orientation }\end{array}$ & Model \\
\hline & KTO & IP management in Cranfield is outsourced to ISIS Innovation. & Tactical & Model \\
\hline & KTO & $\begin{array}{l}\text { CU attempts to recover costs very early in negotiations. } \\
\text { Recovers costs strategically. }\end{array}$ & Strategy, tactical & Operations \\
\hline & Faculty & $\begin{array}{l}\text { Actually there is a lot of help available, but what is missing is } \\
\text { really clarity about it all. There is a clear lack of knowledge in } \\
\text { academics on what help is available and where to look for it. }\end{array}$ & $\begin{array}{l}\text { Tactical, external } \\
\text { orientation }\end{array}$ & Operations \\
\hline \multicolumn{5}{|c|}{ / } \\
\hline & REO & $\begin{array}{l}\text { REO staff engage with local and regional partners and firms } \\
\text { through various formal and informal routes such as business } \\
\text { breakfasts, KTNs, Essex alumni etc. }\end{array}$ & External orientation & Operations \\
\hline & REO & $\begin{array}{l}\text { Essex has done very well with setting up KTPs, even though the } \\
\text { overall number of KTPs have gone down in the sector. }\end{array}$ & Performance & Preference \\
\hline & REO & $\begin{array}{l}\text { Research here is more tilted towards fundamental as opposed to } \\
\text { applied. }\end{array}$ & Strategic & Research \\
\hline & REO & $\begin{array}{l}\text { The REO has the comprehensive mandate of covering research } \\
\text { grants, collaboration management and commercialization of } \\
\text { research. }\end{array}$ & Strategy, tactical & Structure \\
\hline & Faculty & $\begin{array}{l}\text { Colleagues in REO seem to be well tuned with the kind of } \\
\text { research carried out in the departments ... I guess one of the } \\
\text { advantages of operating on a limited scale. }\end{array}$ & Tactical & Structure \\
\hline
\end{tabular}


Table 3. Thematic analysis of University of Oxford

\begin{tabular}{|c|c|c|c|c|}
\hline Themes & Strategy & Tactics & $\begin{array}{l}\text { External } \\
\quad \text { orientation }\end{array}$ & Performance \\
\hline Structure & $\begin{array}{l}\text { Separate RC and AE units. } \\
\text { Spinouts, entrepreneurship } \\
\text { supported by depts. and } \\
\text { faculties. } \\
\text { OUI manages patenting, } \\
\text { licensing, consulting. } \\
\text { Research Services oversees } \\
\text { contracts and } \\
\text { collaborations. }\end{array}$ & $\begin{array}{l}\text { Research Services manages } \\
\text { IP negotiations, but actual } \\
\text { filing of patents and } \\
\text { licensing is managed by } \\
\text { OUI. } \\
\text { Research Services has } 70+ \\
\text { members, many located } \\
\text { physically close to the } \\
\text { researchers. } \\
\text { Multiple channels of } \\
\text { industry engagement } \\
\text { involving staff dedicated } \\
\text { to KT from all across OU. }\end{array}$ & & $\begin{array}{l}\text { Contracts and } \\
\text { collaborations form the } \\
\text { bulk of KT. } \\
\text { Has been very successful in } \\
\text { licensing (on average } 20 \% \\
\text { of patents licensed). } \\
\text { A small number of patents } \\
\text { considered high impact. } \\
\text { Large proportion of revenue } \\
\text { from non-patented IP. }\end{array}$ \\
\hline Location & $\begin{array}{l}\text { OUI is an independent } \\
\text { company. } \\
\text { Research Services is internal } \\
\text { to OU. }\end{array}$ & & $\begin{array}{l}\text { Patenting, licensing, } \\
\text { consultancy management } \\
\text { outsourced. }\end{array}$ & \\
\hline Preference & $\begin{array}{l}\text { All routes of KT explored. } \\
\text { Motivation of RS is } \\
\text { academic, not } \\
\text { commercial. } \\
\text { Motivation of OUI behind } \\
\text { RC is to maximize number } \\
\text { of deals and social benefit. }\end{array}$ & & & $\begin{array}{l}\text { It has been recognized that } \\
\text { research and } \mathrm{KT} \text { are } \\
\text { parallel activities and that } \\
\text { not all researchers can or } \\
\text { will do both. }\end{array}$ \\
\hline Scale & $\begin{array}{l}\text { Research is broad-based } \\
\text { and of high quality. } \\
\text { Research Services and OUI } \\
\text { cover all areas of research }\end{array}$ & & $\begin{array}{l}\text { OUI provides access to } \mathrm{OU} \\
\text { expertise to external } \\
\text { parties. }\end{array}$ & \\
\hline Change & $\begin{array}{l}\text { OUI has to adapt to } \\
\text { changes in global centres } \\
\text { of production. } \\
\text { Move to outsourcing model } \\
\text { has helped to concentrate } \\
\text { on core strength of OU. }\end{array}$ & $\begin{array}{l}\text { Key challenge facing } \mathrm{OU} \text { is } \\
\text { constraints on } \\
\text { translational funding. }\end{array}$ & $\begin{array}{l}\text { OU helping to build a } \\
\text { regional innovation } \\
\text { ecosystem through } \\
\text { interactions with partner } \\
\text { organizations. }\end{array}$ & \\
\hline Research & $\begin{array}{l}\text { Emphasis on excellent } \\
\text { research all round. } \\
\text { 'Wider Engagement with } \\
\text { Society is one of Oxford's } \\
\text { core strategic objectives.' } \\
\text { Excellent research will } \\
\text { eventually lead to 'high } \\
\text { impact' technologies. }\end{array}$ & & $\begin{array}{l}\text { OUI manages an open } \\
\text { innovation forum } \\
\text { involving researchers and } \\
\text { businesses. }\end{array}$ & \\
\hline Operations & $\begin{array}{l}\text { RS acts as a conduit } \\
\text { between researchers and } \\
\text { OUI. }\end{array}$ & $\begin{array}{l}\text { RS has its own dedicated } \\
\text { team dealing with IP } \\
\text { rights management. } \\
\text { OUI recruits staff with } \\
\text { PhDs and/or industry } \\
\text { experience. }\end{array}$ & & $\begin{array}{l}\text { Hands-off approach where } \\
\text { researchers can engage in } \\
\text { KT only if they so wish. }\end{array}$ \\
\hline
\end{tabular}

equally important strategically. As opposed to this stated preference, actual performance reveals that contract research accounts for the bulk of income, followed by collaborations. However, as can be seen in Figure 3, Oxford is one of the few universities in the UK to have seen success in $\mathrm{RC}$ as well as in $\mathrm{AE}$, in line with its strategic intents.

In the case of Durham, the stated preference is for collaborative research, especially those that can be brought under overarching umbrella agreements with commercial partners, 
Table 4. Thematic analysis of University of Durham

\begin{tabular}{|c|c|c|c|c|}
\hline Themes & Strategy & Tactics & $\begin{array}{l}\text { External } \\
\text { orientation }\end{array}$ & Performance \\
\hline Structure & $\begin{array}{l}\text { Separate } \mathrm{RC} \text { and } \mathrm{AE} \\
\text { units, but centralized } \\
\text { within one roof of } \\
\text { DBIS. }\end{array}$ & $\begin{array}{l}\text { Contract research is mostly } \\
\text { channelled through the } \\
\text { departments and centres } \\
\text { directly. }\end{array}$ & & $\begin{array}{l}\text { Contract research is the } \\
\text { largest component of KT. } \\
\text { High impact award winning } \\
\text { collaborative } \\
\text { arrangements have been } \\
\text { established. }\end{array}$ \\
\hline Location & $\begin{array}{l}\text { DBIS located internally } \\
\text { within the university. }\end{array}$ & $\begin{array}{l}\text { External consultants are used } \\
\text { for searches and examining } \\
\text { business cases. } \\
\text { External patent attorneys used } \\
\text { for filing. }\end{array}$ & $\begin{array}{l}\text { Use both internal and } \\
\text { external resources for } \\
\text { marketing newly } \\
\text { developed technologies - } \\
\text { Innovation Commons as } \\
\text { an example of an external } \\
\text { resource. }\end{array}$ & \\
\hline Preference & $\begin{array}{l}\text { DBIS has wide remit but } \\
\text { is increasingly preferring } \\
\text { collaborative umbrella } \\
\text { agreements with one or } \\
\text { more partners. } \\
\text { AE channels clearly } \\
\text { preferred over RC. }\end{array}$ & $\begin{array}{l}\text { Support for spinout vs. } \\
\text { licensing is carried out on a } \\
\text { case by case basis. }\end{array}$ & & $\begin{array}{l}\text { Collaborative research has } \\
\text { increased substantially } \\
\text { recently. } \\
\text { A large number of licenses } \\
\text { have gone into spinouts } \\
\text { historically. Their impact } \\
\text { is yet to be assessed. }\end{array}$ \\
\hline Scale & Research is broad-based. & $\begin{array}{l}\text { Moderately high number of } \\
\text { industrial contracts. } \\
\text { Remit of patenting is generally } \\
\text { UK, EU. }\end{array}$ & & \\
\hline Change & $\begin{array}{l}\text { Moderately late entrant } \\
\text { into KT. } \\
\text { Took a hard look at its } \\
\text { ambitions and } \\
\text { achievements around } \\
2008 \text { and decided to } \\
\text { restructure DBIS and } \\
\text { adopt collaborative } \\
\text { models. }\end{array}$ & $\begin{array}{l}\text { Partnerships require time and } \\
\text { effort to build and sustain. } \\
\text { Sufficient time is provided for } \\
\text { these relationships to mature. } \\
\text { Effort is made to ensure } \\
\text { turnover of people on either } \\
\text { side does not affect } \\
\text { sustainability of project. }\end{array}$ & $\begin{array}{l}\text { 'Licensing and spinouts in } \\
\text { UK have largely remained } \\
\text { unsuccessful.' } \\
\text { 'Other universities are also } \\
\text { moving to a collaborative } \\
\text { model.' }\end{array}$ & $\begin{array}{l}\text { Have decreased the number } \\
\text { of exclusive patents being } \\
\text { filed, move towards joint } \\
\text { filing. } \\
\text { From being a small player } \\
\text { in KT, DU is now at par } \\
\text { with average of Russell } \\
\text { Group universities. }\end{array}$ \\
\hline Research & $\begin{array}{c}\text { Multidisciplinary and/or } \\
\text { co-produced research } \\
\text { encouraged in centres. }\end{array}$ & $\begin{array}{l}\text { DBIS helps to organize } \\
\text { multidisciplinary teams } \\
\text { across DU. }\end{array}$ & & \\
\hline Operations & $\begin{array}{l}\text { Joint IP generation with } \\
\text { industry is preferred. }\end{array}$ & $\begin{array}{l}\text { Continued conversations with } \\
\text { potential and current partners } \\
\text { is key for collaborative } \\
\text { arrangements. } \\
\text { These conversations are held at } \\
\text { multiple levels and contact } \\
\text { points. } \\
\text { New partners may be brought } \\
\text { in over lifetime of one project, } \\
\text { given overlapping interests. }\end{array}$ & & $\begin{array}{l}\text { Relatively small number of } \\
\text { researchers involved with } \\
\text { bulk of KT. } \\
\text { Hands-off approach } \\
\text { followed by DBIS, } \\
\text { academic freedom is kept } \\
\text { intact. }\end{array}$ \\
\hline
\end{tabular}

encompassing multiple independent KT projects. Durham has consciously moved away from a dominant RC-centric model in the past and, although contracts and consultancies currently account for most of the income from $\mathrm{KT}$ activities, it is in the area of long-term multiparty collaborative research initiatives that DBIS wants to invest its resources.
In Cranfield, it is the AE channels - primarily contract research - is seen to play the most important role, and this is reflected in actual income figures as well. The RC route is followed highly selectively, and with early return on investment being the guiding principle in every case.

Finally, in case of Essex, the REO states that it is willing to explore all channels of AE (contracts, 
Table 5. Thematic analysis of Cranfield University

\begin{tabular}{|c|c|c|c|c|}
\hline Themes & Strategy & Tactics & $\begin{array}{l}\text { External } \\
\quad \text { orientation }\end{array}$ & Performance \\
\hline Structure & $\begin{array}{l}\text { Highly devolved model } \\
\text { with no central KTO, } \\
\text { Schools and } \\
\text { departments encouraged } \\
\text { to engage in KT } \\
\text { independently. } \\
\text { Schools, departments and } \\
\text { researchers incentivized } \\
\text { to be entrepreneurial. } \\
\text { A skeletal central team in } \\
\text { place to oversee RC. }\end{array}$ & $\begin{array}{l}\text { The five Schools are run as } \\
\text { independent businesses. } \\
\text { Schools have attached } \\
\text { companies providing research } \\
\text { and contractual support for } \\
\text { AE. } \\
\text { Schools negotiate contracts } \\
\text { independently. } \\
\text { Central skeletal team supports } \\
\text { patenting, licensing, spinouts } \\
\text { with help of OUI, Cranfield } \\
\text { Ventures etc. }\end{array}$ & $\begin{array}{l}\text { Each School has } \\
\text { independent } \\
\text { commercial } \\
\text { companies attached, } \\
\text { which operate as } \\
\text { normal businesses } \\
\text { selling expertise and } \\
\text { services externally. }\end{array}$ & $\begin{array}{l}\text { The independent } \\
\text { companies attached to } \\
\text { Schools are important } \\
\text { sources of revenue for } \\
\text { them. }\end{array}$ \\
\hline Location & $\begin{array}{l}\text { Majority of RC functions } \\
\text { outsourced. }\end{array}$ & $\begin{array}{l}\text { Non-exclusive contract with } \\
\text { OUI, which provides advice, } \\
\text { information etc. } \\
\text { Patent filing, licensing } \\
\text { negotiations carried out } \\
\text { internally. }\end{array}$ & $\begin{array}{l}\text { Outsourced model for a } \\
\text { section KT. } \\
\text { Uses a variety of } \\
\text { external companies for } \\
\text { patent filing, } \\
\text { contracting support. } \\
\text { Spinout support from } \\
\text { Cranfield Ventures, } \\
\text { Business Incubation } \\
\text { Centres and OUI. }\end{array}$ & \\
\hline Preference & $\begin{array}{l}\text { Strong preference for } \\
\text { contract research } \\
\text { followed by other routes } \\
\text { of AE. } \\
\text { Only minimal support for } \\
\text { RC, for those } \\
\text { technologies with very } \\
\text { strong business case. } \\
\text { Strategic approach to } \\
\text { patenting and licensing. }\end{array}$ & $\begin{array}{l}\text { Faculty encouraged to explore } \\
\text { contracts independently and } \\
\text { engage directly in } \\
\text { negotiations. } \\
\text { Financial considerations drive } \\
\text { the decision on whether to } \\
\text { patent certain technologies. } \\
\text { Only those technologies } \\
\text { patented where chances of } \\
\text { immediate licensing is high. }\end{array}$ & $\begin{array}{l}\text { Historically oriented } \\
\text { towards industrial } \\
\text { partnerships with } \\
\text { large blue-chip firms } \\
\text { and defence } \\
\text { establishment. }\end{array}$ & $\begin{array}{l}\text { Contract research } \\
\text { historically accounts } \\
\text { for the largest } \\
\text { component of KT. } \\
\text { CU is one of the few } \\
\text { universities which have } \\
\text { recovered most of its } \\
\text { costs invested into IP } \\
\text { protection and } \\
\text { licensing. }\end{array}$ \\
\hline Scale & $\begin{array}{l}\text { Strong focus on science } \\
\text { and engineering. } \\
\mathrm{CU} \text { is a wholly } \\
\text { postgraduate university. }\end{array}$ & & & \\
\hline Change & $\begin{array}{l}\text { IP management, especially } \\
\text { RC has undergone } \\
\text { radical changes - from } \\
\text { a heavy centralized } \\
\text { presence to being } \\
\text { outsourced. }\end{array}$ & $\begin{array}{l}\text { The subcontracting model was } \\
\text { put in place in } 2006 \text { to } \\
\text { streamline the RC channel } \\
\text { and make it financially viable. } \\
\text { Initial contract with Imperial } \\
\text { Ventures, which was } \\
\text { subsequently changed to } \\
\text { OUI. }\end{array}$ & $\begin{array}{l}\text { The emphasis on } \\
\text { external partnerships } \\
\text { with industry has } \\
\text { remained unchanged, } \\
\text { but modes and } \\
\text { processes of have } \\
\text { undergone changes. }\end{array}$ & \\
\hline Research & $\begin{array}{l}\text { CU embodies twin } \\
\text { objectives of academic } \\
\text { rigour and financial } \\
\text { viability as part of its } \\
\text { long-term strategy and } \\
\text { treats these } \\
\text { independently. } \\
\text { Strong applied focus. } \\
\text { Historically close to } \\
\text { industry and } \\
\text { defence-related topics. }\end{array}$ & $\begin{array}{l}\text { Faculty encouraged to explore } \\
\text { RC and AE options very early } \\
\text { in the lifetime of a research } \\
\text { project. } \\
\text { No apparent conflict between } \\
\text { publication and KT motives. } \\
\text { Researchers may not always be } \\
\text { aware of all alternatives, } \\
\text { especially when they are new. }\end{array}$ & $\begin{array}{l}\text { Applied industry } \\
\text { relevant research is } \\
\text { encouraged. }\end{array}$ & \\
\hline
\end{tabular}


Table 5. Continued

\begin{tabular}{|c|c|c|c|c|}
\hline Themes & Strategy & Tactics & $\begin{array}{l}\text { External } \\
\text { orientation }\end{array}$ & Performance \\
\hline Operations & $\begin{array}{l}\text { Recovery of costs from } \\
\text { investments in KT and } \\
\text { financial considerations } \\
\text { are given high priority }\end{array}$ & $\begin{array}{l}\text { Researchers incentivized for } \\
\text { being entrepreneurial and } \\
\text { active in KT. } \\
\text { Independent consulting by } \\
\text { researchers are not } \\
\text { encouraged. } \\
\text { Relationship with OUI flexible } \\
\text { and non-exclusive. }\end{array}$ & & $\begin{array}{l}\text { IP-related contracts are } \\
\text { put in place early in } \\
\text { any research project's } \\
\text { lifetime. } \\
\text { Attempts are made very } \\
\text { early to recover costs } \\
\text { related to IP protection } \\
\text { and licensing. }\end{array}$ \\
\hline
\end{tabular}

collaborations, consultancies and alternative routes such as KTPs), but places little emphasis on $\mathrm{RC}$ routes. This has been reflected in its performance in recent years, with growth in contracts, collaborations and the KTP route.

\section{Context and implications}

While the distinction and similarities between the local models have been discussed above, evaluating the context becomes necessary to understand the background and evolution of these models. We discuss each university in turn.

For Oxford, the primary feature of the university is the extremely large volume and width of research output, both applied and fundamental in nature. This is backed by its reputation for high quality across the board and a distinguished history of path-breaking research. At the same time, KT and research impact is one of Oxford's strategic objectives. As the above discussion shows (see Table 3), Oxford has adopted a partially outward-facing but mostly centralized model, where a degree of outsourcing combined with internal devolution is the main feature. The volume and quality of research probably makes the outsourcing model a necessary ingredient in its KT setup. At the same time, these characteristics of Oxford's research enable the external partnership with OUI to be sustainable and successful.

Table 4 provides the thematic analysis for Durham. Like Oxford, Durham is a Russell Group university with a broad research base, with a focus largely on fundamental research. The analysis also reveals that DBIS has been involved in a few highly successful collaborative ventures in the past, involving several independent projects within umbrella agreements. Such agreements had materialized after sustained contact and dialogue between the partner organizations at multiple levels. Resources were invested by all concerned to sustain them in the long run. Effort was put in to redirecting some of the in-house research to be relevant for the collaborators, often involving multidisciplinary research centres and teams, which DBIS helped to organize. Durham Business \& Innovation Services went through a period of restructuring and realignment in 2008, following an introspective exercise carried out by the university regarding its KT performance, ambitions and strategies.

For such collaborative umbrella agreements to be successful, the benefits of long-term collaborations must be apparent to all parties from the beginning. Moreover, contact between the participating organizations needs to be at multiple levels and should be sustainable irrespective of turnover of people. Also, the KTO must be well connected with different departments and be aware of ongoing research projects and their potential.

Table 5 provides thematic analysis of the data obtained from Cranfield and illustrates its uniqueness in many respects. Cranfield has historically championed close links with business and industry, aiming to combine the rigour of academics and long-term thinking with the applied mind-set and problem-solving focus of industry. It has close ties with industry from early on, with an emphasis on science and engineering research throughout. Cranfield embodies the twin objectives of academic rigour and financial viability in their long-term strategy, and hence explicitly encourages researchers to be entrepreneurial. It is also a wholly post-graduate university with a narrow research focus.

While the devolved approach minimizes resource requirements for a centralized KTO, and allows for localized flexibility within departments, some additional criteria need to be fulfilled for its success. First, a well-designed set of incentives for 
Table 6. Thematic analysis of University of Essex

\begin{tabular}{|c|c|c|c|c|}
\hline Themes & Strategy & Tactics & $\begin{array}{l}\text { External } \\
\text { orientation }\end{array}$ & Performance \\
\hline Structure & $\begin{array}{l}\text { REO is centralized and } \\
\text { manages all aspects of } \\
\text { KT. }\end{array}$ & $\begin{array}{l}\text { Income-sharing arrangements } \\
\text { are generously in favour of } \\
\text { researchers. }\end{array}$ & & \\
\hline Location & $\begin{array}{l}\text { REO is located wholly } \\
\text { within the university. }\end{array}$ & & $\begin{array}{l}\text { REO uses external } \\
\text { partners for technology } \\
\text { evaluation, patent filing } \\
\text { etc. }\end{array}$ & \\
\hline Preference & $\begin{array}{l}\text { Does not discriminate } \\
\text { between various channels, } \\
\text { but finds RC challenging, } \\
\text { given the nature of } \\
\text { research in UE. } \\
\text { Increasingly the focus is on } \\
\text { specialized channels of } \\
\text { AE. }\end{array}$ & $\begin{array}{l}\text { Actively explores alternative } \\
\text { models of AE, such as KTPs } \\
\text { and Innovation Voucher } \\
\text { systems. } \\
\text { KTPs are popular and have } \\
\text { been frequently used in the } \\
\text { last five years. }\end{array}$ & & $\begin{array}{l}\text { UE has witnessed a growth } \\
\text { KTPs recently, with a } \\
\text { number of on-going and } \\
\text { completed projects. } \\
\text { A small number of spinouts } \\
\text { have been supported by } \\
\text { the REO in recent years. }\end{array}$ \\
\hline Scale & $\begin{array}{l}\text { REO has a comprehensive } \\
\text { mandate of managing } \\
\text { research grants, as well as } \\
\text { all aspects of KT. } \\
\text { There is a strong focus on } \\
\text { social science and } \\
\text { humanities disciplines. }\end{array}$ & $\begin{array}{l}\text { REO provides support for all } \\
\text { avenues of } \mathrm{KT} \text {. }\end{array}$ & & \\
\hline Change & $\begin{array}{l}\text { Traditionally attempted to } \\
\text { carry out RC, but given } \\
\text { UE's poor record in RC, it } \\
\text { is increasingly exploring } \\
\text { AE channels more. } \\
\text { 'There is a lot of potential } \\
\text { for Essex to increase } \\
\text { revenue from knowledge } \\
\text { transfer.' } \\
\text { There is need for a change } \\
\text { in the way research is } \\
\text { carried out in UE. }\end{array}$ & & & $\begin{array}{l}\text { Contracts and } \\
\text { collaborations have been } \\
\text { established as well, not in } \\
\text { traditional science and } \\
\text { technology domains, but } \\
\text { in social science and } \\
\text { humanities. } \\
\text { Overall figures are still } \\
\text { modest, but there has } \\
\text { been significant growth in } \\
\text { revenue from KT activities } \\
\text { in recent years. }\end{array}$ \\
\hline Research & $\begin{array}{l}\text { Research largely focuses } \\
\text { around social sciences and } \\
\text { humanities, with only a } \\
\text { few strong science and } \\
\text { technology departments. } \\
\text { The focus is more around } \\
\text { blue-sky research rather } \\
\text { than applied. }\end{array}$ & $\begin{array}{l}\text { Research is carried out in small } \\
\text { teams within departments. } \\
\text { Research teams lack critical } \\
\text { mass. }\end{array}$ & & $\begin{array}{l}\text { Researchers are becoming } \\
\text { aware of KT } \\
\text { opportunities, especially } \\
\text { through recent successes } \\
\text { in KTPs. There is growing } \\
\text { interest in exploring KT } \\
\text { avenues. } \\
\text { The emphasis placed by } \\
\text { Research Councils on } \\
\text { research impact has also } \\
\text { contributed towards } \\
\text { growing interest in KT. }\end{array}$ \\
\hline Operations & & $\begin{array}{l}\text { Although centralized, given } \\
\text { overall size REO has } \\
\text { dedicated managers for } \\
\text { FACULTIES and } \\
\text { departments who are able to } \\
\text { liaise with academic } \\
\text { researchers directly if needed. } \\
\text { REO does not aggressively } \\
\text { pursue KT opportunities } \\
\text { allowing researchers to bring } \\
\text { potential ideas to them. }\end{array}$ & & $\begin{array}{l}\text { KTPs and Innovation } \\
\text { Vouchers are easier to set } \\
\text { up, and seen to be } \\
\text { preferred by } \\
\text { small-to-medium firms. }\end{array}$ \\
\hline
\end{tabular}


Table 7. Comparison of the case studies with respect to KT organization and research outcomes in each

\begin{tabular}{|c|c|c|c|c|}
\hline \multirow[b]{2}{*}{ Characteristics } & \multicolumn{4}{|c|}{ Cases } \\
\hline & Oxford & Durham & Cranfield & Essex \\
\hline Research quality & $\begin{array}{l}\text { Very high and highly } \\
\text { reputed }\end{array}$ & High & Medium low & Medium low \\
\hline Research breadth & $\begin{array}{l}\text { Very broad, covering all } \\
\text { disciplines }\end{array}$ & $\begin{array}{l}\text { Broad, but especially } \\
\text { reputed for science and } \\
\text { technology }\end{array}$ & $\begin{array}{l}\text { Narrow, with focus on } \\
\text { science and technology }\end{array}$ & $\begin{array}{l}\text { Narrow, with focus on } \\
\text { social sciences }\end{array}$ \\
\hline Structure of KTO & $\begin{array}{l}\text { Partly centralized. Explicit } \\
\text { division between RC } \\
\text { and AE responsibilities }\end{array}$ & $\begin{array}{l}\text { Centralized. Implicit } \\
\text { division between RC and } \\
\text { AE responsibilities }\end{array}$ & $\begin{array}{l}\text { Devolved to Schools and } \\
\text { departments }\end{array}$ & Centralized \\
\hline $\begin{array}{l}\text { Business model of } \\
\text { KTO }\end{array}$ & $\begin{array}{l}\text { Partly outsourced } \\
\text { (RC and Consulting) }\end{array}$ & Internal & Outsourced & Internal \\
\hline $\begin{array}{l}\text { Strategic preference } \\
\text { for channels (by } \\
\text { value) }\end{array}$ & $\begin{array}{l}\text { Stated: all RC and AE } \\
\text { channels }\end{array}$ & $\begin{array}{l}\text { Stated: AE, generally } \\
\text { collaborations through } \\
\text { umbrella agreements }\end{array}$ & $\begin{array}{l}\text { Stated: AE, generally } \\
\text { contracts }\end{array}$ & Stated: all AE channels \\
\hline $\mathrm{RC}$ success & Very successful & Not successful & $\begin{array}{l}\text { Moderately successful. } \\
\text { Good return on } \\
\text { investment. }\end{array}$ & Not successful \\
\hline AE success & $\begin{array}{l}\text { Very successful, mostly } \\
\text { contracts }\end{array}$ & $\begin{array}{l}\text { Moderately successful, } \\
\text { mostly contracts }\end{array}$ & $\begin{array}{l}\text { Successful, mostly } \\
\text { contracts. }\end{array}$ & $\begin{array}{r}\text { Moderately successful, } \\
\text { contracts and KTPs }\end{array}$ \\
\hline
\end{tabular}

individuals, departments and Schools is essential. Second, a high level of awareness of KT opportunities, requirements and processes is needed. Finally, even if the same overarching financially driven strategy is applied to all academic units across the university, it is essential that adjustments are made locally in Schools or departments, depending on the disciplines and research focus. For instance, the School of Business in Cranfield is very distinct from the other Schools in its focus, and hence a more flexible approach has been adopted.

Table 6 provides the thematic analysis for Essex. This is a relatively new institution compared with the others, especially well known for research in social sciences and in humanities, with a limited number of scientific departments. It differs significantly in character from both Oxford and Durham, which offer a wide breadth of research across all disciplines, and from Cranfield, which has a strong engineering and technology focus. Despite a limited focus on science and technology, Essex does have a positive record of KT, mostly attributable to AE in social science and humanities disciplines.

Given its relatively narrow research focus, both $\mathrm{RC}$ and AE have been a challenge for the university historically. Like most of the others in our study, Essex also has had to reorient its organizational policies on KT towards using its strengths in social sciences and humanities. Academic Engagement routes have been used to connect reasonably well with small-to-medium companies, who would have otherwise found it difficult to engage with universities. Essex's preference for the AE route is understandable, given its prominence in social science and humanities-oriented research, where the distinction between what is truly 'applied' vs. 'fundamental' can be blurred. In such cases, it is difficult for the research itself to find a ready home for use, or in other words for supply to create its own demand.

In such cases, KT needs to be more 'demand driven', and this is where the role of the REO becomes critical. The REO must be proactive in searching for possible avenues where such demand exists. In Essex's case, researchers themselves provide assistance through personal contacts in industry wherever possible. However, barring a few exceptions, research in general is more oriented towards the fundamental variety, which may have resulted in a perceived gap between the functioning of the REO and the research activities within majority of the departments. There is a perception that the REO can be more proactive in bringing in business than has been the case in the past. And this is also where the REO can probably use networking initiatives such as the KTNs and business meetings more effectively to 'sell' the research output created in the University of Essex (UE). 

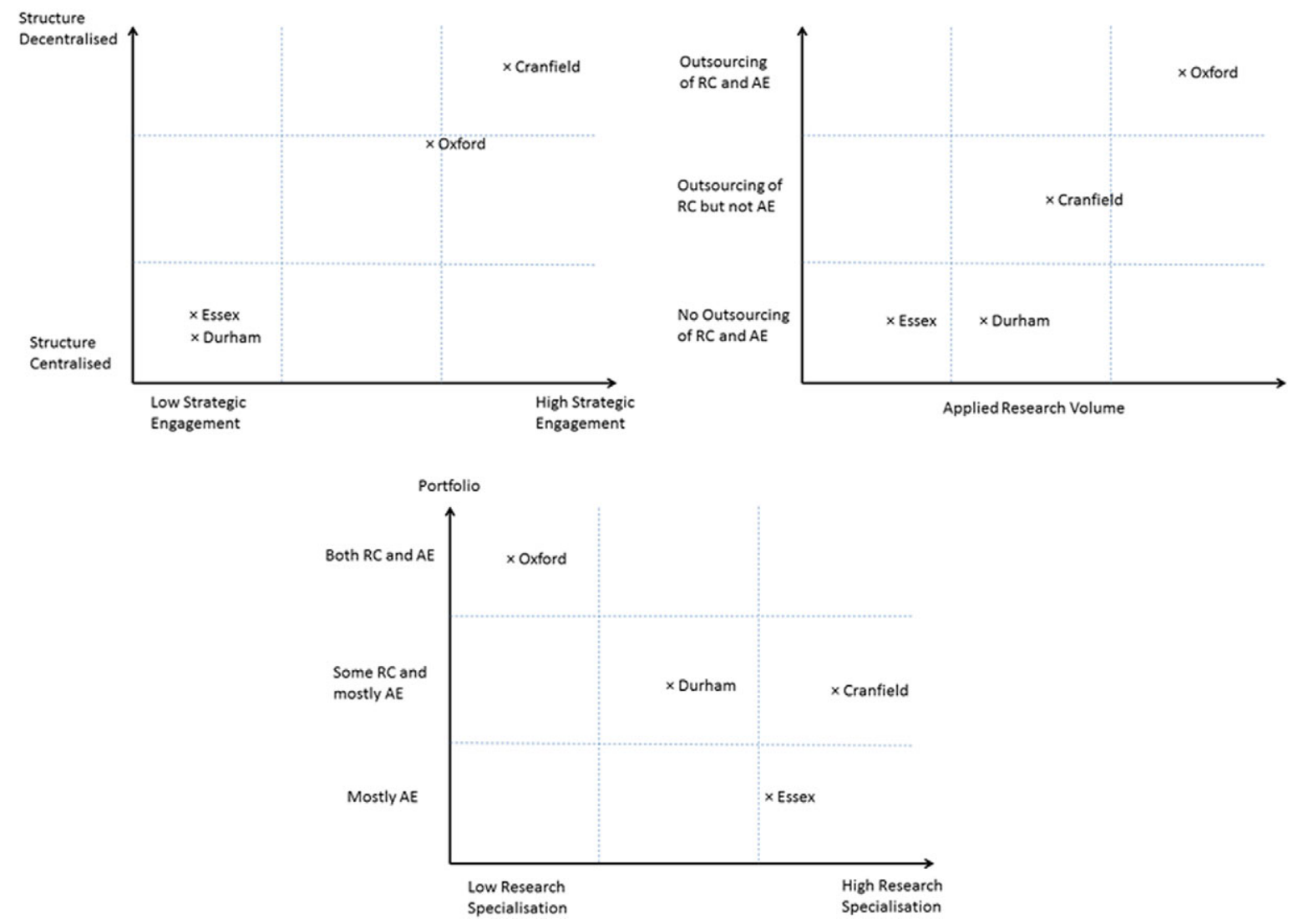

Figure 4. Mapping of case study universities in terms of (a) centralization vs. strategic engagement with users, (b) level of outsourcing vs. applied research volume, (c) portfolio preference vs. research specialization [Colour figure can be viewed at wileyonlinelibrary.com]

\section{Discussion}

Prior research focusing on the antecedents and impacts of RC and AE activities in universities has largely overlooked the organizational aspects of KTOs themselves. This has resulted in a gap in the literature, which, given the structural shifts in the higher educational landscape, can no longer be ignored, and which this paper begins to address. The findings presented here examine these organizational aspects and their potential determinants. We find that universities seem to have evolved very different KT frameworks locally where contextual factors have played an important role. This implies that KTOs can be, and in fact need to be, organizationally heterogeneous across the sector. Among the contextual factors, we find that strategic priorities of the university and the nature of research are central in influencing the organizational features of the KTO and its activities.
The case studies highlight the importance of the nature (applied vs. fundamental) of research, breadth (specialization) of research and universitylevel strategic priorities. Given that the analysis focused on four key organizational characteristics of KTOs - structure, business model and portfolio preference - we now map out the relationships that emerged between these organizational characteristics and the key contextual factors. Figure 4 maps out the key aspects of the KT model within the case studies and organizational research characteristics: (a) level of centralization of KTO activities vs. strategic engagement with end users of research; (b) level of outsourcing of core KT functions vs. volume of applied research; and (c) channel-specific performance vs. research specialization. The overarching differences in the local models, when juxtaposed against the differences in university-level characteristics, reveal clear patterns, which are stated in a set of propositions. 


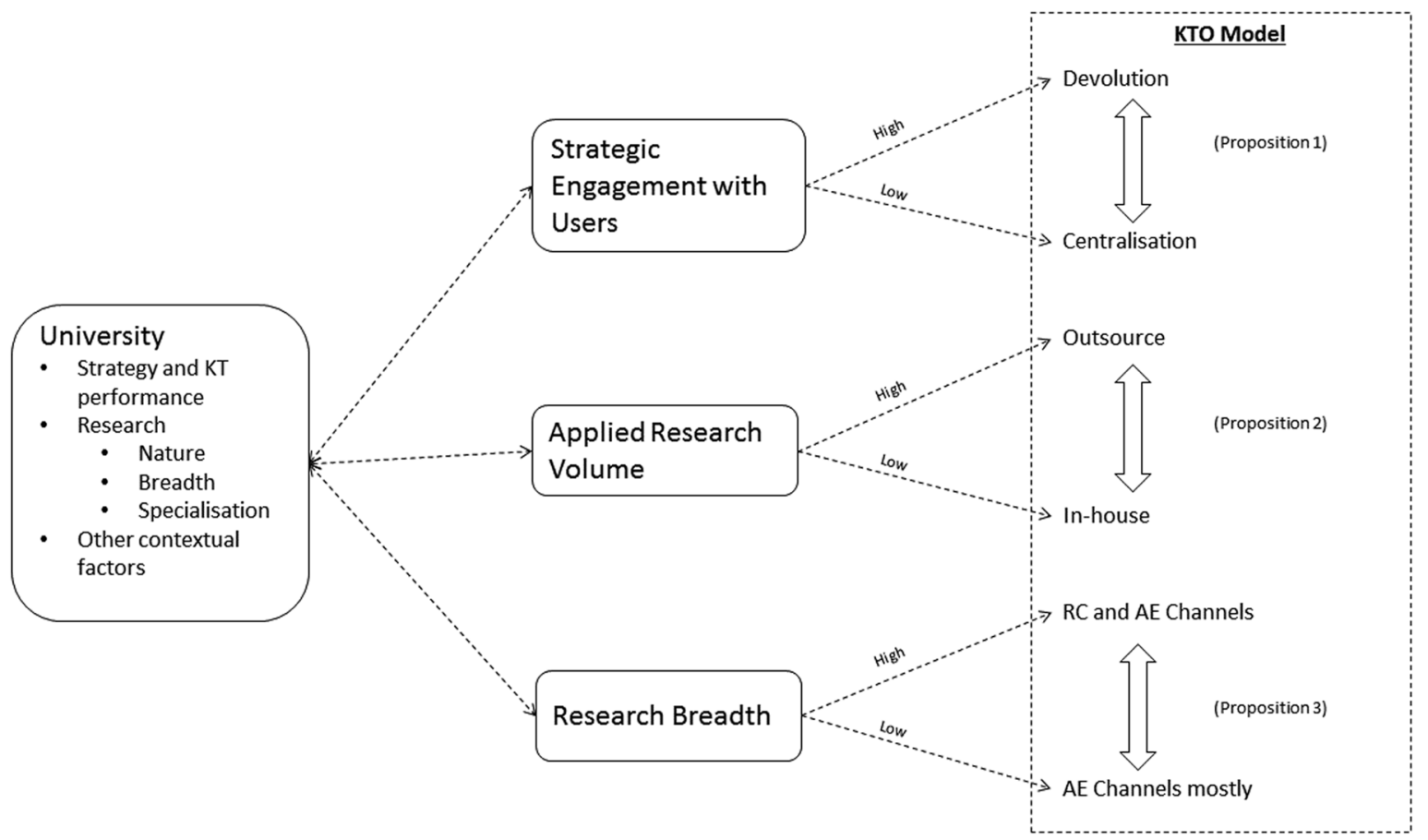

Figure 5. Findings - linking university-level features with the KTO's characteristics

P1 (Structure): Universities that explicitly embody engagement with research users as part of their strategy are more inclined to devolve a higher proportion of KT responsibilities to academic units, away from a centralized KTO.

Cranfield's and Oxford's models form the basis of Proposition 1 and links the strategic focus of the university with the underlying structure of the KTO (Figure 4a). This finding is in line with previous organizational literature, where the interplay between strategy and structure in an organization has been stressed upon (Miller, 1987), especially in the context of knowledge management (Hedlund, 1994). It has been shown that the opportunities and incentives for KT varies across departments and research specializations (Siegel, Veugelers and Wright, 2007; Wright. Birley and Mosey, 2004). Hence, it is only natural that universities more strategically focused engaging practitioners would provide flexibility to academic units to shape their own KT framework according to discipline specific needs.

P2 (Business model): Universities exhibiting relatively high volumes of application oriented research outputs are more inclined to outsource wholly or partly, its key KT functions to external organizations.
This is evidenced in the models adopted in both Oxford and Cranfield and their differences with those in Durham and Essex (Figure 4b). Given the scale of applied research in Oxford and Cranfield, it is tactically important for the KTO to outsource large portions of core functions to specialist intermediaries. As KT becomes more central to its core operations and as the volume of applied output increases in its research offering, it becomes necessary for a university to explore alternative business models to streamline operations and increase efficiency. The role of intermediaries to whom key operations may be outsourced to reduce overheads and for access to specialist knowledge becomes important in this scenario (Morris, Schindehutte and Allen, 2005).

Interestingly, in the cases examined here, it is the RC functions that have been outsourced, while $\mathrm{AE}$ has largely been retained in-house, either centrally or devolved to the departments. Given the relatively poor performance of $\mathrm{RC}$ channels compared with $\mathrm{AE}$ in the $\mathrm{UK}$, it is likely that universities are increasingly adopting a cautious approach to licensing and spinouts (Lockett et al., 2005; Siegel and Wright, 2015), and outsourcing indicates a degree of diversification in risk. This highlights the importance of strategic responses of universities, especially in response to the changes 


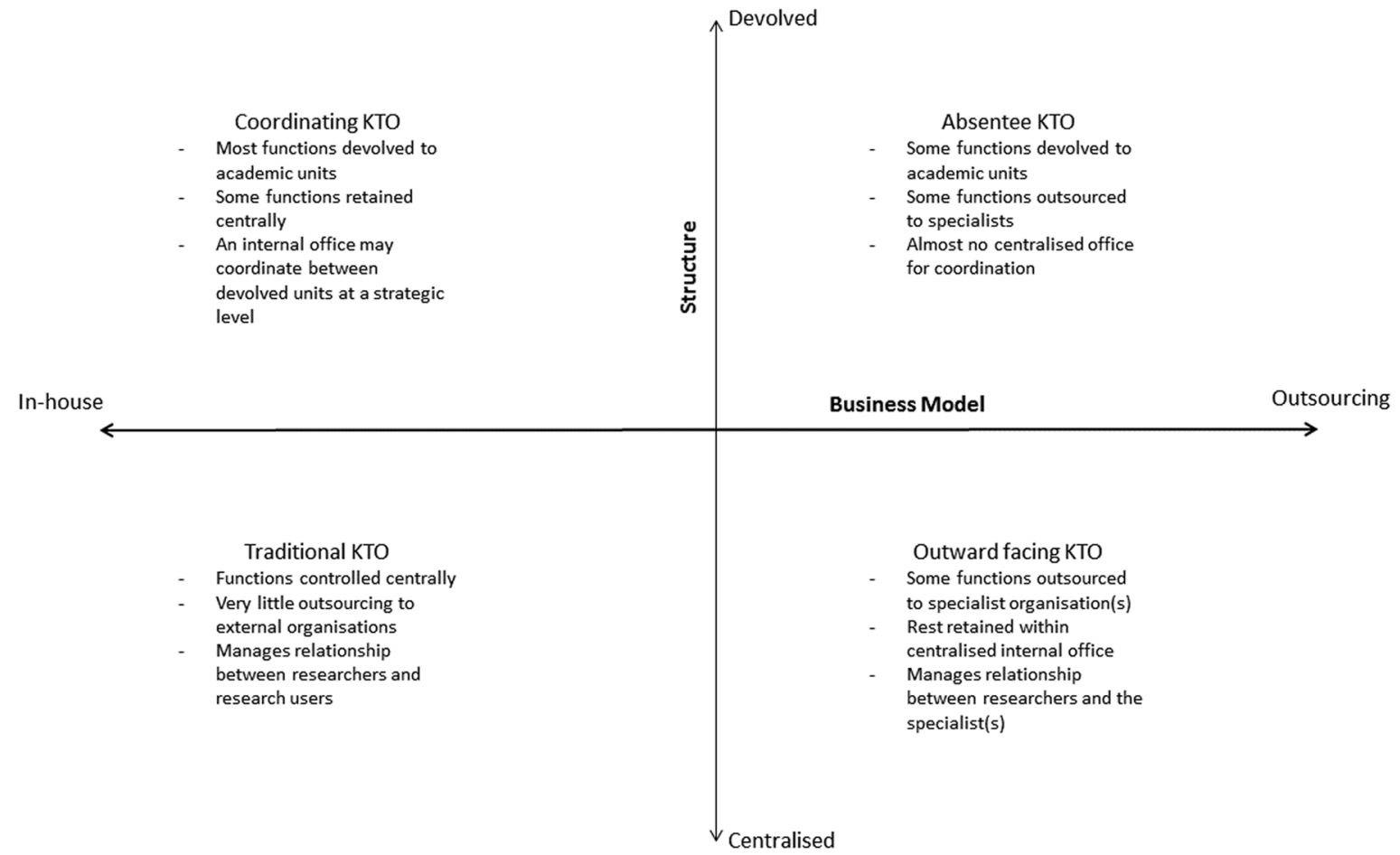

Figure 6. Generic models of KTO, based on structure and business model

in the higher education ecosystem (Martin, 2012).

This leads us to the next proposition, which links preference for $\mathrm{RC}$ and $\mathrm{AE}$ with research specialization. It has already been established that the presence of more applied disciplines, such as engineering or bio-medicine increase the likelihood of KT (Bekkers and Bodas Freitas, 2008; Bozeman and Gaughan, 2007; Ponomariov, 2008). The following proposition generalizes this further.

P3 (Portfolio): Preference for KT channels depends on the specialization in their research. More specialized universities limited by the number of research-active disciplines would prefer channels involving $\mathrm{AE}$, whereas those with a broader research focus discriminate between channels of RC or AE to a lesser degree.

While Bekkers and Bodas Freitas (2008) show the impact of specific disciplines on channel choice, our result hints at a more general effect of research specialization. Both Cranfield and Essex are highly focused in specialized fields of research, whereas Oxford is not. Both Cranfield and Essex have shown a strong preference for AE channels. Oxford, in contrast, states no special preference for any particular channel, and which is also reflected in its relatively superior performance in RC compared with universities in the UK. Durham falls somewhere in-between, and has also shown a clear preference for the AE channel, although $\mathrm{RC}$ is nevertheless carried out (Figure 4c).

These propositions form the basis of the first theoretical contribution of this paper, which is summarized in Figure 5. In the section headed 'Background', we presented the broad conceptual framework underpinning our analysis, and Figure 5 connects this framework to the overall findings presented in the propositions. What emerges is a pattern of how specific contextual factors affect specific key characteristics of the local KT model implemented in the university.

Our next contribution comes in the form of a set of generic KT models based on structure and business model. It is possible to abstract away from the contextual factors of the case studies and derive generic models of KT based on the key characteristics examined here. These are shown in the four quadrants in Figure 6, where level of outsourcing of $\mathrm{KT}$ activities is presented along the $X$-axis, and structure devolution is presented along the $Y$-axis. Note that portfolio preference would ideally form 
the third dimension, and may be overlaid on Figure 6 to provide further variation to these models.

Knowledge Transfer Offices originally started out being specialized centralized offices within universities (Phan and Siegel, 2006) and, in many cases, have retained this character (for instance in Essex). The Traditional model points towards this approach. As universities evolve and incorporate practitioner engagement within their strategic portfolio, it makes sense for the KTOs to devolve more of their functions to departments - with the central office playing a coordinating role, as has been implemented to some degree in both Oxford and Durham. When scale effects of a large volume of applied research set in, it makes sense for the KTO to adopt an outsourcing model, which may be coupled with a devolved approach (Absentee KTO) or may retain some level of central control through an outward-facing KTO. The former is more of the characteristic of Cranfield, while the latter resembles what is found in Oxford.

Each model has its own benefits and costs, and further variation is possible along the portfolio dimension. The actual adoption of one by a university would depend largely on contextual factors local to the university. And KTOs may choose to move from one quadrant to another (and change channel preferences at the same time), given changes in the local context (Durham and Cranfield). It is also possible for the KTO to adopt a hybrid framework that combines two or more generic models (such as in Oxford).

\section{Conclusion}

This paper provides a theoretical understanding of the organizational framework of KTOs, addressing a crucial gap in the literature. Previous literature has mostly considered the organizational features of a KTO as given, and examined its impact on KT performance. However, given that third mission activities have become integral to universities, understanding the framework within which they are carried out is crucial from both an academic and a practitioner point of view. Our paper goes to the heart of the choices available to university managers in designing and implementing a local KT model, and connects these choices to the university context.
Since this is one of the first attempts to understand this phenomenon, it is not without its limitations. Given that our findings are based on a small sample, caution needs to exercised when interpreting the propositions. First, it is entirely possible that each of these contextual factors affect more than one aspect of the KTO, which our small sample has not been able to capture. Secondly, the case analyses were not able to uncover the impact of other factors such as age, location, nature of KTO managerial staff or features of the student population, which might have an impact on the KTO's activities. And finally, given the cross nature of the study, we were not able to explore potential feedback effects of the locally implemented KT model on university-level characteristics.

The theoretical contribution in this paper paves the way for further studies to examine the links between contextual factors and organizational setup in further detail. We established that the KTOs and localized processes not only act as a key enabler in creating and maintaining opportunities for transfer of knowledge, but are themselves shaped and structured by the history and characteristics of the universities of which they are a part. The frameworks and generic KT models presented here provide a useful point of reference and a template, which can be adapted according to their unique needs and characteristics.

\section{References}

Acs, Z. J., D. B. Audretsch and M. P. Feldman (1992). 'Real effects of academic research: comment', American Economic Review, 82, pp. 363-367.

Ambos, T. C., M. Birkinshaw, J. Kristina and P. D'Este (2008). 'When does university research get commercialized? Creating ambidexterity in research institutions', Journal of Management Studies, 45, pp. 1424-1447.

Azagra-Caro, J. M., F. Archontakis, A. Gutiérrez-Garcia and I. Fernández-de-Lucio (2006). 'Faculty support for the objectives of university-industry relations versus degree of R\&D cooperation: the importance of regional absorptive capacity', Research Policy, 35, pp. 37-55.

Bekkers, R. and I. M. Bodas Freitas (2008). 'Analysing knowledge transfer channels between universities and industry: to what degree do sectors also matter', Research Policy, 37, pp. 1837-1853.

Belcourt, M. (2006). 'Outsourcing - the benefits and the risks', Human Resource Management Review, 16, pp. 269-279.

Belenzon, S. and M. Schankerman (2009). 'University knowledge transfer: private ownership, incentives and local development objectives', Journal of Law and Economics, 52, pp. 111-144.

Bercovitz, J., M. Feldman, I. Feller and R. Burton (2001). 'Organizational structure as determinants of academic patent and 
licensing behaviour: an exploratory study of Duke, Johns Hopkins, and Pennsylvania State Universities', Journal of Technology Transfer, 26, pp. 21-35.

Berman, E. M. (1990). 'The economic impact of industry-funded university R\&D', Research Policy, 19, pp. 349-355.

Bozeman, B. and M. Gaughan (2007). 'Impacts of grants and contracts on academic researchers' interactions with industry', Research Policy, 36, pp. 694-707.

Brettel, M., C. Chomik and T. C. Flatten (2014). 'How organizational culture influences innovativeness, proactiveness, and risk-taking: fostering entrepreneurial orientation in SMEs', Journal of Small Business Management, 53, pp. 868885.

Chandler, A. (1962). Strategy and Structure: Chapters in the History of the American Industrial Enterprise. Cambridge, MA: MIT Press.

Chapple, W., A. Lockett, D. S. Siegel and M. Wright (2005). 'Assessing the relative performance of university technology transfer offices in the UK: parametric and non-parametric evidence', Research Policy, 34, pp. 369-434.

Chen, C.J. and J. W. Huang (2007). 'How organizational climate and structure affect knowledge management - the social interaction perspective', International Journal of Information Management, 27, pp. 104-118.

Cohen, W. M., R. R. Nelson and J. P. Walsh (2002). 'Links and impacts: the impact of public research on industrial R\&D', Management Science, 48, pp. 1-23.

Cosh, A., X. Fu and A. Hughes (2012). 'Organisation structure and innovation performance in different environments', Small Business Economics, 39, pp. 301-317.

Cummings, T. G. and C. G. Worley (2015). Organizational Development and Change, 10th edn. Boston, MA: Cengage Learning.

Damanpour, F. (1991). 'Organizational innovation: a metaanalysis of effects of determinants and moderators', Academy of Management Journal, 34, pp. 555-590.

Debackere, K. and R. Veugelers (2005). 'The role of academic technology transfer organizations in improving industry science links', Research Policy, 34, pp. 321-342.

Deiaco, E., A. Hughes and M. McKelvey (2012). 'Universities as strategic actors in the knowledge economy', Cambridge Journal of Economics, 36, pp. 525-541.

D'Este, P. and P. Patel (2007). 'University-industry linkages in the UK: what are the factors underlying the variety of interactions with industry?', Research Policy, 36, pp. 1295-1313.

D’Este, P. and M. Perkmann (2011). 'Why do academics engage with industry? The entrepreneurial university and individual motivations', Journal of Technology Transfer, 36, pp. 316339.

Eisenhardt, K. and M. E. Graebner (2007). 'Theory building from cases: opportunities and challenges', Academy of Management Journal, 50, pp. 25-32.

Etzkowitz, H., A. Webster, C. Gebhardt and B. R. C. Terra (2000). 'The future of the university and the university of the future: evolution of ivory tower to entrepreneurial paradigm', Research Policy, 29, pp. 313-330.

Geuna, A. and L. J. J. Nesta (2006). 'University patenting and its effects on academic research: the emerging European evidence', Research Policy, 35, pp. 790-807.

Geuna, A. and F. Rossi (2011). 'Changes to university IPR regulations in Europe and the impact on academic patenting', Research Policy, 40, pp. 1068-1076.
Gibbert, M., W. Ruigrok and B. Wicki (2008). 'What passes as a rigorous case study?', Strategic Management Journal, 29, pp. 1465-1474.

Guerrero, M. and D. Urbano (2012). 'The development of an entrepreneurial university', Journal of Technology Transfer, 37, pp. 43-74.

Guerrero, M. and D. Urbano (2014). 'Academics' start-up intentions and knowledge filters: an individual perspective of the knowledge spillover theory of entrepreneurship', Small Business Economics, $\mathbf{4 3}$, pp. 57-74.

Guerrero, M., D. Urbano, A. Fayolle, M. Klofsen and S. Mian (2016). 'Entrepreneurial universities: emerging models in the new social and economic landscape', Small Business Economics, 47, pp. 551-563.

Haeussler, C. and J. A. Colyvas (2011). 'Breaking the Ivory Tower: academic entrepreneurship in the life sciences in UK and Germany', Research Policy, 40, pp. 41-54.

Hayter, C. S. (2016). 'A trajectory of early-stage spinoff success: the role of knowledge intermediaries within and entrepreneurial university ecosystem', Small Business Economics, 47, pp. 633-656.

HE-BCI Report (2014). Higher Education - Business and Community Interaction Survey 2013-14. Report prepared for Higher Education Funding Council for England (HEFCE). Available at: http://www.hefce.ac.uk/pubs/year/2015/201513/ [accessed 28 January 2017].

Hedlund, G. (1994). 'A model of knowledge management and the $\mathrm{N}$-form corporation', Strategic Management Journal, 15(S2), pp. 73-90.

Hewitt-Dundas, N. (2012). 'Research intensity and knowledge transfer activity in UK universities', Research Policy, 4, pp. 262-275.

Howells, J. (2006). 'Intermediation and the role of intermediaries in innovation', Research Policy, 35, pp. 715-728.

Hughes, A. and M. Kitson (2012). 'Pathways to impact and strategic role of universities: new evidence on the breadth and depth of university knowledge exchange in the UK and the factors constraining its development', Cambridge Journal of Economics, 36, pp. 723-750.

Huyghe, A., M. Knockaert, E. Piva and M. Wright (2016). 'Are researchers deliberately bypassing the technology transfer office? An analysis of TTO awareness', Small Business Economics, 47, pp. 589-607.

Lach, S. and M. Schankerman (2004). 'Royalty sharing and technology licensing in universities', Journal of the European Economic Association, 2, pp. 252-264.

Lee, J.-N. and Y.-G. Kim (1999). 'Effect of partnership quality on IS outsourcing success: conceptual framework and empirical validation', Journal of Management Information Systems, 15, pp. 29-61.

Lee, S. and B. Bozeman (2005). 'The impact of research collaborations on scientific productivity', Social Studies of Science, 35, pp. 673-702.

Lee, Y. S. (1998). 'University-industry collaboration on technology transfer: views from the Ivory Tower', Policy Studies Journal, 26, pp. 69-84.

Link, A. N. and D. S. Siegel (2005). 'Generating science-based growth: an econometric analysis of the impact of organizational incentives on university-industry technology transfer', European Journal of Finance, 11, pp. 169-181.

Lockett, A., M. Wright and A. Wild (2015). 'The institutionalization of third stream activities in UK Higher Education: the 
role of discourse and metrics', British Journal of Management, 26, pp. 78-92.

Lockett, A., D. Siegel, M. Wright and M. Ensley (2005). 'The creation of spin-off firms at public research institutions: managerial and policy implications', Research Policy, 34, pp. 98193.

Martin, B. R. (2012). 'Are universities and university research under threat? Towards an evolutionary model of university speciation', Cambridge Journal of Economics, 36, pp. 543565.

Miles, R. E., C. C. Snow, A. D. Meyer and H. J. Coleman Jr (1978). 'Organizational strategy, structure and process', Academy of Management Review, 3, pp. 546-562.

Miller, D. (1987). 'Strategy making and structure: analysis and implications for performance', Academy of Management Journal, 30, pp. 7-32.

Miller, K., M. McAdam and R. McAdam (2014). 'The changing university business model: a stakeholder perspective', $R \& D$ Management, 44, pp. 265-287.

Morris, M., M. Schindehutte and J. Allen (2005). 'The entrepreneur's business model: towards a unified perspective', Journal of Business Research, 58, pp. 726-735.

Mowery, D. C. and B. N. Sampat (2005). 'The Bayh-Dole Act of 1980 and university-industry technology transfer: a model for other OECD governments?', Journal of Technology Transfer, 30, pp. 115-127.

Mowery, D. C., R. R. Nelson, B. N. Sampat and A. A. Ziedonis (2004). Ivory Tower and Industrial Innovation: UniversityIndustry Technology Transfer Before and After the Bayh-Dole Act. Palo-Alto, CA: Stanford University Press.

O'Kane, C., V. Mangematin, W. Geoghegan and C. Fitzgerald (2015). 'University technology transfer offices: the search for identity to build legitimacy', Research Policy, 44, pp. 421437.

Perkmann, M. and K. Walsh (2007). 'University-industry relationships and open innovation: towards a research agenda', International Journal of Management Reviews, 9, pp. 259280.

Perkmann, M. and K. Walsh (2009). 'The two faces of collaborations: impacts of university-industry relations on public research', Industrial and Corporate Change, 18, pp. 10331065.

Perkmann, M., Z. King and S. Pavelin (2011). 'Engaging excellence? Effects of faculty quality on university engagement with industry', Research Policy, 40, pp. 539-552.

Perkmann, M., V. Tartari, M. McKelvey, E. Autio, A. Brostrom, P. D'Este, R. Fini, A. Geuna, A. Hughes, S. Krabel, M. Kitson, P. Llerena, F. Lissoni, A. Salter and M. Sobrero (2013). 'Academic engagement and commercialisation: a review of the literature on university-industry relations', Research Policy, 42, pp. 423-442.

Phan, P. H. and D. S. Siegel (2006). 'The effectiveness of university technology transfer', Foundations and Trends in Entrepreneurship, 2, pp. 77-144.

Ponomariov, B. (2008). 'Effects of university characteristics on scientists' interactions with the private sector: an exploratory assessment', Journal of Technology Transfer, 33, pp. 485503.

Ponomariov, B. and P. C. Boardman (2008). 'The effect of informal industry contacts on the time university scientists allocate to collaborative research with industry', Journal of Technology Transfer, 33, pp. 301-313.
Quinn, J. B. (1999). 'Strategic outsourcing: leveraging knowledge capabilities', Sloan Management Review, 40, pp. 9-21.

Ray, A. S. and S. Saha (2010). 'Patenting public-funded research for technology transfer: a conceptual-empirical synthesis of US evidence and lessons for India', Journal of World Intellectual Property, 14, pp. 75-101.

Rossi, F. and A. Rosli (2015). 'Indicators of university-industry knowledge transfer performance and their implications for universities: evidence from the United Kingdom', Studies in Higher Education, 40, pp. 1970-1991.

Sengupta, A. and A. S. Ray (2015). 'University research, commercialisation and knowledge exchange in the UK: an econometric analysis of the determinants and inter-linkages'. Working Paper, ESRC Business and Local Government Data Research Centre.

Sharifi, H., W. Liu and H. S. Ismail (2013). 'Higher education system and the "open" knowledge transfer: a view from perception of senior managers at university knowledge transfer offices', Studies in Higher Education, 39, pp. 18601884.

Siegel, D. S. and M. Wright (2015). 'Academic entrepreneurship: time for a rethink?', British Journal of Management, 26, pp. 582-595.

Siegel, D., R. Veugelers and M. Wright (2007). 'Technology transfer offices and commercialization of university intellectual property: performance and policy implications', Oxford Review of Economic Policy, 23, pp. 640660.

Siegel, D. S., D. A. Waldman and A. N. Link (2003). 'Assessing the impact of organizational practices on the productivity of university technology transfer offices: an exploratory study', Research Policy, 32, pp. 27-48.

Slaughter, S. and L. L. Leslie (1997). Academic Capitalism: Politics, Policies, and the Entrepreneurial university. Baltimore, MD: Johns Hopkins University Press.

Thursby, J. G. and M. C. Thursby (2002). 'Who is selling the ivory tower? Sources of growth in university licensing', Management Science, 48, pp. 90-104.

Weckowska, D. M. (2015). 'Learning in university technology transfer offices: transactions-focused and relations-focused approaches to commercialization of academic research', Technovation, 41-42, pp. 62-74.

Williamson, O. (1975). Markets and Hierarchies: Analysis and Antitrust Implications. New York, NY: Free Press.

Williamson, O. (1985). The Economic Institutions of Capitalism. New York, NY: Free Press.

Wolfe, R. A. (1994). 'Organizational innovation: review, critique and suggested research directions', Journal of Management Studies, 31, pp. 405-431.

Wright, M., S. Birley and S. Mosey (2004). 'Entrepreneurship and university technology transfer', Journal of Technology Transfer, 29, pp. 235-46.

Wright, M., B. Clarysse, P. Mustar and A. Lockett (2007). Academic Entrepreneurship in Europe. London: Edgar Elgar.

Wright, M., B. Clarysse, A. Lockett and M. Knockaert (2008). 'Mid-range universities' linkages with industry: knowledge types and the role of intermediaries', Research Policy, 37, pp. 1205-1223.

Yusuf, S. (2008). 'Intermediating knowledge exchange between universities and businesses', Research Policy, 37, pp. 11671174. 
Dr. Abhijit Sengupta is based at the Essex Business School at the University of Essex. His research interests lie in areas of $R \& D$ management, innovation, intellectual property, market dynamics and complex systems. He received a PhD in Economics from Stony Brook University, New York, in 2005.

Professor Amit S. Ray is based at the Centre for International Trade and Development, Jawaharlal Nehru University, India. He received his DPhil in Economics in 1988 from the University of Oxford. His research is focused on issues of Technology and R\&D, Intellectual Property Rights, Health Economics, Pharmaceutical Industry, Foreign Direct Investment and a wide range of policy issues.

\section{Supporting Information}

Additional Supporting Information may be found in the online version of this article at the publisher's website:

Supplementary Material 